\section{Research Square}

Preprints are preliminary reports that have not undergone peer review.

They should not be considered conclusive, used to inform clinical practice, or referenced by the media as validated information.

\title{
Impact of CSA Innovations on Household Food and Nutrition Security: Evidence From the Upper Blue Nile Highland of Ethiopia
}

Abyiot Teklu ( $\sim$ abyiot.teklu@aau.edu.et)

Addis Ababa University College of Development Studies https://orcid.org/0000-0001-5557-8262

Belay Simane

Addis Ababa University College of Development Studies

Mintewab Bezabih

EDRI: Ethiopian Development Research Institute

\section{Research}

Keywords: Food security, physical SWC, crop residue management, compost, agroforestry, ESR, Ethiopia

Posted Date: December 20th, 2021

DOI: https://doi.org/10.21203/rs.3.rs-1173148/v1

License: () (i) This work is licensed under a Creative Commons Attribution 4.0 International License. Read Full License 


\section{Abstract}

Background: Food insecurity remains a major challenge to smallholder farmers in the face of changing climate in the Upper Blue Nile Highlands of Ethiopia. To improve food and nutrition security of climate change vulnerable smallholder farmers in eastern Ethiopia, several climate-smart agriculture (CSA) innovations have been adopted and scaled-up. However, the impact of these innovations on household food and nutritional security was not systematically studied. This study examined the impact of selected CSA technologies on household food and nutrition security. Cross-sectional data were generated from 424 randomly selected rural smallholder agriculture households in the five selected agroecosystems of the Upper Blue Nile Highlands of Ethiopia. The study employed propensity score matching and endogenous switching regression estimation models.

Results: Households that practiced crop residue management had an 8.46 higher Food Consumption Score (FCS) and a 0.4 higher Household Dietary Diversity Score (HDDS) than non-adopters. Similarly, households who adopted compost and agroforestry had a 0.462 and 0.446 higher Household Dietary Diversity Score (HDDS) than non-adopters, respectively. The endogenous switching regression analysis result showed that households that practiced crop residue management had an 22.6 higher Food Consumption Score (FCS) and a 2.2 higher Household Dietary Diversity Score (HDDS) than non-adopters. Similarly, households who adopted physical SWC had a 2.3 higher Food Consumption Score (FCS) than non-adopters. Whereas, compost and agroforestry had a 0.28 and 2.12 higher Household Dietary Diversity Score (HDDS) than non-adopters, respectively.

Conclusions: This shows that households adopting CSA innovations are more likely to have higher food security compared to non-adopters. This suggests that promotion and scale-up of CSA innovations in the study area can enhance household food and nutrition security.

\section{Introduction}

Climate change poses threats to food systems by affecting all components of food security: food availability, food accessibility, food utilization, and food stability, exacerbating long-standing development challenges of reducing poverty, ensuring food security, and achieving the sustainable development goals( SDGs) (Kotir, 2011; Teklewold, Gebrehiwot, et al., 2019). Climate change causes reduction in crop yield, market changes, food price increases, and supply chain infrastructure destruction (Adhikari et al., 2015; IPCC, 2014; Kotir, 2011) as a result of warming, changing precipitation patterns, and the increased frequency of extreme events such as drought and flood, as well as their consequences (IPCC, 2019).

Climate change in Ethiopia has manifested itself as an increase in average daily temperature at a variable rate, an intensification of inter-annual and intrapersonal precipitation variability, and a decrease in growing period from 120 days to 90 days in most places (T. Belay et al., 2013; Meze-hausken, 2004; Tseganeh, Hengsdijk, Ro“tter, et al., 2013; Tseganeh, Hengsdijk, Rötter, et al., 2013; Bewket Woldeamlak, 2013).

Food insecurity has been a major issue in Ethiopia for decades due to series of production failures that resulted in chronic food insecurity since the 1970 s. Since 1950, twelve major drought induced food security crises have occurred (NMA, 2007). Rainfall is one of the main climatic determinants of food production in Ethiopia as wetter years are generally associated with higher food production while dry years are associated with lower production (D. et al., 2011).

In Ethiopia, rain-fed agriculture is the mainstay of the rural society, accounting for approximately 77 percent of the population, subsistence, practiced on too small land size to be viable, with low input and low yield, and exposed to climate change risk (Belay \& Winfried, 2004; Chamberlin \& Schmidt, 2013).

In Ethiopia, food security is extremely vulnerable to climate change. Historical and recent climate-related events, such as the food security crises in the Horn of Africa in 2008/2009 and 2011, as well as the 2015/2016 El Nino effect, have highlighted the impact of droughts and floods on food production, market access, and agricultural income (Kosmowski, 2018). Thus, the increased risk of climate change has exacerbated low yield that made agriculture the primary sector of the economy where the effects of climate change-induced shocks have been felt (Deressa et al., 2011; Di Falco \& Veronesi, 2013; Teklewold et al., 2017).

Ethiopia's smallholder agriculture suffers from decline of land productivity, land degradation, shortage of land, low input use, water scarcity, and low adaptive capacity (Ermias et al., 2013; Gebremicael et al., 2013; Simane et al., 2016). When climate change couples with these problems, the smallholder agriculture system suffers from further reduction of productivity, increasing water shortage, and low adaptive capacity to respond to the risk of climate change (Simeneh \& Fisseha, 2016; Yibekal et al., 2013).

In addition, except for the progress made during the last two and half decades, the agricultural sector in Ethiopia had remained stagnant for centuries with limited progress in few specific areas due to a combination of declining soil fertility, population growth, low uptake of external inputs, and climate change related disasters such as droughts (Bachewe et al., 2018; Tsigab et al., 2019).

In addition to the importance of food availability, food access is critical for food security in Ethiopia: even in the most productive areas as poorer farmers purchase some of their food, so households depend heavily on markets and in-kind contributions, during the agricultural lean seasons (WFP, 2014). Crops stored for lean season may be damaged due to crop-pastes caused by changing climate. Moreover, due to climate change hazard such as flood, infrastructures such as roads will be washed away or closed that hinders access to market and exacerbate shortage of available food consumption in the summer lean season (Melak \& Birgit, 2014; Bewket. Woldeamlak, 2012).

Ethiopia's highlands are more vulnerable to climate change because of wide variation in topography, climate, and agroecosystems. Sloping areas represent the most fragile lands in the highlands, as they are highly susceptible to erosion. Agricultural expansion has been carried out at the expense of natural resources degradation (particularly forests, water and soils) (Ermias et al., 2013; Gebremicael et al., 2013; Niang et al., 2014; Pender \& Ehui, 2006; G. Samuel, 2006; Simane et al., 2016; Yalew et al., 2012). 
The Choke mountain watershed is part of the Blue Nile highlands that are known to be surplus producing region and water tower of the Blue Nile(Bewket Woldeamlak, 2001). Agriculture is the main economic activity and source of livelihood. The farming system is characterized by wheat- maize-teff dominated mixed crop-livestock production system. The Ethiopian ard (or maresha), an ancient plow, is used for tillage that led to high rates of on-field erosion, particularly on steep slopes (Simane et al., 2016). Overgrazing and deforestation have also contributed to erosion and soil fertility decline. Livestock feed shortages(open grazing) and fuelwood demands continue to exert significant pressure on the resource base (Bewket Woldeamlak \& Sterk, 2005). Hence, the watershed is threatened by land and water resource degradation and impending food shortage (Ermias et al., 2013). Consequently, low agricultural productivity, severe land degradation, and climate change and variability have become the characteristic of this area (Bewket Woldeamlak \& Sterk, 2005).

As a result, Ethiopia has launched the Climate-Resilient Green Economy (CRGE) initiative to reduce the economic impact of climate change, particularly on agriculture, and to build a green economy capable of reaching middle-income status through adoption of crop and livestock production innovation for higher food security and income while reducing GHGs emission in agriculture by 2030 (FDRE, 2019). One of the approaches the CRGE implemented since 2012 is adoption of CSA innovations in crop and livestock sector.

Several literatures show that smallholder agriculture can enhance food security, adapt to climate change or resilience, and reduce GHG emissions through adopting different set of CSA technologies such as sustainable land management (SLM), intercropping, crop rotation, soil and water conservation, modern input use, and agroforestry (Arslan et al., 2015; Deichert et al., 2017; Hailemariam, Alemu, Kohlin, 2017; Hailemariam et al., 2019; Hengsdijk \& Verhagen, 2013; Jirata et al., 2016; Komarek et al., 2019; Makate, 2019; Paulos \& Belay, 2017; Rimhanen et al., 2012; Teklewold, Mekonnen, et al., 2019; Tsige et al., 2020).

In Ethiopia, although there are no standard criteria to label an agriculture technology as CSA or not, MOA and GIZ has developed a CSA manual that identified some of the technologies CSA. According to the manual, crop residue management, crop rotation, compost, soil and water conservation measures, agroforestry, and improved variety were identified as CSA (Deichert et al., 2017).

Moreover, achieving the three goals of increasing food security, enhancing sustainable adaptability, and contributing to the reduction or removing of the greenhouse gases (GHGs) from the atmosphere to limit the global temperature below $20 \mathrm{C}$ above pre-industrial levels has been a daunting agricultural development policy challenge (IPCC, 2019). Because, adoption of CSA innovations has become a challenging issue in the agricultural development policy agenda for sub-Saharan Africa chiefly eastern Africa (Leal Filho et al., 2015; Lipper et al., 2014). Inspite of different initiatives to enhance the uptake of CSA technologies through the public agricultural extension programs through training in the FTCs, on-farm demonstration, peer guiding, and provision of awareness creation campaigns, adoption rate of CSA is quite low in rural areas of developing countries even with several national and international initiatives to encourage the adoption (Asfaw et al., 2015; Kpadonou et al., 2017).

As far as the existing literature is concerned, studies on CSA are recent phenomenon and limited in Ethiopia (Hailemariam, Alemu, Kohlin, 2017; Jirata et al., 2016; Negra et al., 2014; Rimhanen et al., 2012). In some of this literature, CSA has been studied as a single practice or anecdote (Hailemariam, Alemu, Kohlin, 2017) and others as only carbon sequestration or climate mitigation (Rimhanen et al., 2012). Moreover, numerous literature exists on climate change adaptation strategies (Asmare et al., 2019; Simane \& Asrat, 2018; Temesgen \& Rashid, 2009; Tesfaye \& Seifu, 2016; Weldegebriel \& Prowse, 2013; B. Woldeamlak et al., 2015; Yesuf \& Ringler, 2008), yet there is limited literature on impact of CSA innovations.

Although impact and effect of technologies were studied in Ethiopia, the literature approaches focus on piece meal technologies impact such as soil and water conservation on runoff, soil and nutrient losses, and crop yield, row planting on household welfare (Adimassu et al., 2017; Tamirat, 2020). Most empirical studies focuses on adaptation strategies to climate change in Ethiopia rather than the impact of CSA innovations on food security (Alem et al., 2016; Rosenzweig \& Hillel, 2015; Tazeze et al., 2012a; Teklewold, Mekonnen, et al., 2019). There are few studies on the ex-post impact assessment of adoption of CSA innovations, particularly in the Upper Blue Nile Highlands of Ethiopia (Hailemariam et al., 2017; Teklewold, Tagel, et al., 2019). However, these studies have limited insight to the impact of CSA innovations on food security at the micro level, taking food security measurements. Thus, quantifying the impact of CSA innovations requires rigorous effort to study in order to inform policy makers about the magnitude of the impacts to improve the food security of smallholder farmers.

The main purpose of this paper is to examine the impact of adoption of CSA innovations on household food and nutrition security. This study contributes to the literature from the micro perspective of the impact of adoption of CSA innovation on household food security. As, the empirical evidence of the impact of CSA innovations on food security will help fill the knowledge gap in the study area, the study area.

\section{Conceptual Framework}

Farmers' decisions to adopt farm technologies depend on the economic benefits associated with these practices, among other things, food security is the most important one (Lopez-Ridaura et al., 2018). Adoption of CSA innovations directly affects crop-livestock productivity, non-food agricultural production such as fuel wood lot, and off farm activities. The food stack from agriculture is used for household food consumption while the sales from agricultural products and fuel wood lots as well as the income from pity trade (selling of traditional drink areki of widowed women) helps to access food from the market and pay for health and water sanitation. The feedback due to climate change will affect the decision to adopt CSA innovations. Moreover, the increase in food security of the household will increase the welfare of the household and increases adoption of CSA innovations that enhances food security. Thus, improving agricultural productivity is a means for enhanced availability of food, rural income and other livelihood assets for farm households. These relationships occur in a wider environment of a given location. Hence, the core components (adoption of CSA innovations decisions and productivity) and their interrelationships can further be affected and conditioned by climate change, personal(socio-demographic), economic, institutional, and environmental factors (Arslan et al., 2015; Asfaw et al., 2014; Duguma et al., 2014; FAO, 2013; World Food Programme, 2008). Accordingly, the possible link among climate change, adoption of climate smart technologies, and food security status as well as the role of various factors (technological, institutional, environmental and policy) affecting these relationship is illustrated Figure 1. 


\section{Measuring Food Security}

There are several measurement of food security and food insecurity from the household level to the country. A number of indicators are used to measure food security at household level, and these commonly include: The Household Dietary Diversity Score (HHDS); Copying Strategy Index (CSI) and the Food Consumption Score (FCS). In this study food security is measured at the household level.

The suitability of each of these indicators depends on the given food shortage situation and intend use of the information. This study concerned about both the quality and quantity consumed by households. Hence, the FCS and HDSS were a more suitable indicator of food security. The HHDS indicates the diversity of the dietary intake of a household and the FCS shows the quantity and quality of food actually consumed by a household. The seven days' recall HDDS were used due to the seven-day similar consumption of pattern of households. Food consumption score(FCS) encompasses the food availability and food access of the food security (Maxwell et al., 2013; Wekesa et al., 2018). FCS is a composite score based on the dietary diversity, food frequency, and relative nutritional importance of the various food groups consumed. The higher the FCS, the higher is the dietary diversity and frequency. High food consumption increases the possibility that a household achieves nutrient adequacy (WFP, 2009). Food availability were taken care of by food consumption score through the food that is physically present in the area through all forms of domestic production (crop farming and livestock), and food stock. Food access were measured in the FCS through a household's ability to acquire food regularly through one or a combination of home production and stocks, purchases, barter, gifts, borrowing, and food aid. Food utilization is included through household's frequency of the utilization of the available food or accessed food. Although, the household score is compared with pre-established thresholds that indicate the status of the household's food consumption such as poor food consumption (0 to 21); borderline food consumption (21.5 to 35); and acceptable food consumption (greater than 35). For the description and analysis of food security situation of the household, both the continuous and discrete FCS categories were used in this study. The threshold FCS category is used for describing the food security status of the households while the continuous FCS composite score was used for its ease of analysis for the econometric modeling as dependent variable.

\section{Methodology}

\subsection{Study area}

The Choke mountain watershed is located in Ethiopia's Blue Nile Highlands (BNHs). The Choke Mountain Watershed is roughly located between $9^{\circ} 38^{\prime} 00^{\prime \prime}$ and $10^{\circ} 55^{\prime} 24^{\prime \prime}$ North latitude and $37^{\circ} 07^{\prime} 00^{\prime \prime}$ to $38^{\circ} 17^{\prime} 00^{\prime \prime}$ East longitude. It is located at an elevation of 2100 to 4113 meters above sea level. The total land surface area of the Watershed is approximately $15,950 \mathrm{~km} 2$. The watershed's average annual rainfall ranges between 200 and 2200 millimeters. The average annual temperature ranges from $11.5^{\circ} \mathrm{C}$ to $27.5^{\circ} \mathrm{C}$, and the Watershed's slope gradient ranges from flat to steep. The watershed contains eight dominant soil types: Alisols, Andosols, Cambisols, Leptosols, Luvisols, Nitosols, Phaeozems, and Vertisols. The climate of the watershed ranges from the hot arid climate of the Abay (Blue Nile) gorge to the cold and moist climate of the peak of the Choke Mountain (Simane et al., 2013).

The choke mountain watershed is divided into six distinct agroecosystem zones, according to (Simane et al., 2013). The lowland and valley fragmented agroecosystem zone (AESZ1), the midland with black soil agroecosystem zone (AESZ2), the midland with brown soil agroecosystem zone (AESZ3), the midland sloping land agroecosystem zone (AESZ4), and the hilly and mountainous highlands agroecosystem zone (AESZ5), and the afro alpine (AES6).

\subsection{Sampling design and data collection}

Quantitative data was gathered using a structured household survey questionnaire that focused on household and farm characteristics was collected on a one-to-one interview basis by well-trained and experienced enumerators using android tablets. The instruments collected information from household heads on socio-demographic characteristics, economic characteristics, use of institutions and infrastructure, climate-smart agriculture innovations, livelihood assets, and climate risk perceptions.

The study sites and respondents were chosen using a multi-stage sampling technique followed by systematic random sampling. The first stage involved choosing five woredas in the BNH based on the five Agro-ecosystems zones (AESZs), then kebeles from each woreda. Finally, using a one-to-five community mobilization group register and a probability proportional to size (PPS) sampling procedure, a systematic random sampling technique was used to select 424 households from the five kebeles (Table 1).

Table 1

Sample woredas and kebeles

\begin{tabular}{|lllll|}
\hline No & Woredas & Kebeles & Sample size & Agroecosystem zone (AESZ) \\
\hline 1 & Dejen & Gelgele & 77 & AESZ1: Lowland agroecosystem \\
\hline 2 & Awobel & Enebi & 55 & AESZ2: Midland with black soil \\
\hline 3 & Basoliben & Limichim & 104 & AESZ3: Midland with brown soil \\
4 & Machakel & Debre Kelemua & 63 & AESZ4: Midland with sloping land \\
\hline 5 & Sinan & Yeted & 125 & AESZ5: The hilly and mountainous highland \\
& Total & & $\mathbf{4 2 4}$ & \\
\hline
\end{tabular}

\subsection{Data analysis}


The data was subjected to descriptive analysis in order to obtain frequencies and cross-tabulations that showed the data's relationships. The chi-square statistic was used to determine whether variations in agroecosystem zone between adopters and non-adopters of CSA innovation in the research area were statistically significant.

The adoption of CSA innovations and its impact on food security can be modeled in the setting of a two-stage framework. In the first stage, we use a selection model for CSA innovations adoption where a smallholder farmer chooses to implement CSA innovations if its gains with regard to food security outweighs the loss incurred due to its adoption. Let $\mathrm{G}^{*}$ be the latent variable that captures the expected food security gains from its adoption with respect to not adopting. the latent variable is specified as

$\mathrm{G}^{*}=Z_{i} \alpha+u_{i}$ with $\mathrm{G}_{\mathrm{i}}=1$ if $\mathrm{G}_{\mathrm{i}}^{*}>0$ otherwise $\mathrm{G}_{\mathrm{i}}=0$

That is, farmer i will adopt CSA innovation $\left(G_{i}=1\right)$ in response to different socio-demographic, economic, institutional, and environmental factors, if $G_{i}^{*}>0$ otherwise 0 . The vector $Z$ represents variables that maximize the farmer's food security gains by adopting CSA innovations. In the model, socio-demographic characteristics of the farmer e.g., sex, age, education, farm experience, climate change and CSA awareness. It is also important to address the role of economic factors such as total farm size, livestock holding, and access to saving and credit facilities. Also institutional factor, access to agricultural extension, access to communication, access to market, and tenure security. Finally, environmental factors of soil fertility slope of farm land, and climate change risk perceptions.

In the second stage, the effect of CSA innovation adoption on food security is measured and represented of measures of food consumption score (FCS). The easiest way to examine the impact of adoption of CSA technology on FCS would be to include in the regression of FCS equation a dummy variable equal to 1 if the farm household adopted a particular CSA technology, and then, to apply ordinary least squares (OLS). This approach, however, might yield biased estimates because it assumes that adoption of CSA technologies is exogenously determined while it is potentially endogenous. The decision to adopt or not is voluntary and may be based on individual self-selection. In order to avoid the problem of selection bias propensity score matching (PSM) and Endogenous switching regression were used.

\section{Results And Discussion}

\subsection{Food security status of the households}

According to the result of food security analysis, adopters of improved variety, crop residue management, and row planting have significant (p0.01) higher FCS than non-adopters. Adopters of SWC, on the other hand, have significant (p0.05) lower FCS than non-adopters. In terms of food utilization, household dietary diversity score (HDDS), adopters of improved variety, crop residue management, compost, row planting and agroforestry have strongly higher HDDS than nonadopters. Hence, adoption significantly increased food quality and quantity of the household. As a result, improved variety (p0.01), crop residue management (p0.01), compost (p0.01), row planting (p0.01), and agroforestry (p0.01) have significantly increased the food availability, access and utilization component of food security, while SWC have significantly decreased the food availability and access component of food security. Therefore, improved variety, crop residue management, compost, row planting, and agroforestry have increased CSA innovations adopters' food security. However, mean comparison is not immune from statistical bias due to self-selection and unobserved factors and further impact evaluation analysis techniques are needed to reveal the true effect of adoption of CSA innovation on household food security (Table 3).

Table 3

Comparison of FCS and HDDS of adopters and non-adopters of CSA innovations

\begin{tabular}{|c|c|c|c|c|c|c|}
\hline \multirow[t]{2}{*}{ CSA Innovations } & \multicolumn{3}{|c|}{ Food consumption score(FCS) } & \multicolumn{3}{|c|}{ Household Dietary Diversity Score (HDDS) } \\
\hline & Adopter & Non adopter & t value & Adopter & Non adopter & t value \\
\hline Improved variety & $40.6(1.0)$ & $37.1(0.6)$ & $3.0 * \star *$ & $4.24(0.10)$ & $3.78(0.06)$ & $3.99 * * *$ \\
\hline Crop residue management & $42.2(0.7)$ & $34.7(0.7)$ & $7.3^{\star \star \star}$ & $4.11(0.09)$ & $3.76(0.06)$ & $3.22^{\star \star \star}$ \\
\hline Crop rotation & $37.4(0.9)$ & $38.6(0.7)$ & 1.0 & $4.03(0.11)$ & $3.87(0.06)$ & 1.41 \\
\hline Compost & $38.4(0.7)$ & $37.8(0.9)$ & 0.6 & $4.09(0.07)$ & $3.60(0.07)$ & $4.29 * \star \star$ \\
\hline Row planting & $38.9(0.6)$ & $36.2(1.1)$ & $2.1^{\star \star}$ & $4.06(0.06)$ & $3.49(0.09)$ & $4.61^{\star \star \star}$ \\
\hline Physical SWC & $35.4(0.8)$ & $41.0(0.7)$ & $-5.3^{\star \star \star}$ & $3.84(0.08)$ & $4.01(0.07)$ & -1.63 \\
\hline Agroforestry & $38.9(1.1)$ & $38.0(0.6)$ & 0.7 & $4.43(0.15)$ & $3.79(0.05)$ & $4.78^{\star \star \star}$ \\
\hline
\end{tabular}

\subsection{Empirical modeling of the effect of CSA innovations on food security} 5.2.1 Propensity Score matching (PSM) 
The study used the propensity score matching a non-parametric technique. To estimate the average treatment effect, the estimates of the propensity score on the treated (ATT), matched treated, and non-treated farming households were calculated using logistic regression. The overlap condition was imposed and the balancing property was set and satisfied among adopters of CSA innovations.

Table 4 presents the estimated results of the logit model for the selection of CSA innovations. Education has a positive and significant influence on adoption of crop residue management, physical SWC, and agroforestry. Climate change awareness has a negative and significant effect on adoption of physical SWC while CSA awareness has a positive and significant effect on adoption of crop residue management, compost, physical SWC, and agroforestry. As expected, there is significant and positive association between CSA awareness of the household head and adoption of crop residue management, compost, physical SWC, and agroforestry. Awareness to climate change and adaptation strategies may increase the individual's ability to respond to the risk of climate change and adopt various farm management practices. Our finding is supported by, among others, awareness of climate change influenced climate change adaptation strategies (O. O. Samuel \& Sylvia, 2019). Furthermore, these finding concurs with households' adaptation to climate change was found positively and significantly affected by education, livestock holding, cooperatives membership, extension services, farmers income and households perception to climate change (Gebru et al., 2020).

Total farm size has a positive and significant effect on adoption of crop residue management, compost, physical SWC, and agroforestry. The finding is concurrent with (G. Belay et al., 2017) that reported that bigger farm size accrues benefits of economies of scale to farmers and also provide a means of diversifying production. Number of plots cultivated has a negative and significant effect on adoption of crop residue management. Access to credit has a positive and significant effect on adoption of physical SWC. Adoption of SWC is less likely for credit-constrained farm households that liquidity-constrained households (those who need credit but are unable to get it) are less likely to adopt practices that require cash outlay. Access to extension service has a positive and significant effect on adoption of physical SWC while negative and significant effect on adoption of crop residue management and agroforestry. These findings were supported by other findings who reported that access to credit, agro ecological zones, access to climate information, and extension contact have a significant impact on climate change adaptation strategies (Diallo et al., 2020; Tazeze et al., 2012b).

Long distance to market (lack of access to market) has a positive and significant effect on adoption of compost. Access to energy saving technology (improved cook stove) has a positive and significant influence on adoption of crop residue management, compost, and physical SWC. Access to water (stand pipe and tube well) have a positive and significant effect on adoption of crop residue management. 'Wenfel' has a negative and significant effect on adoption of compost and physical SWC. Strong tenure security has a positive and significant effect on adoption of crop residue management and agroforestry.

Poor soil fertility has a positive and significant influence on adoption of agroforestry while a negative influence on adoption of compost. Slope of farm land has a positive and significant effect on adoption of crop residue management and compost. Climate change risk perception of increasing trend of temperature has a positive and significant effect on adoption of crop residue management and agroforestry. Similarly, climate change risk perception of increasing trend of hailstorm has a positive and significant effect on adoption of crop residue management and physical SWC.

Furthermore, farmers who live in AES1 are more likely to adopt physical SWC while less likely to adopt compost and agroforestry because AES1 is hilly and degraded land in the Abay gorge. Farmers who lives in AES3 is associated with adoption of crop residue management, compost and agroforestry while less likely to adopt physical SWC. Similarly, farmers who live in AES4 are less likely to adopt crop residue management due to lack of sufficient crop residue. Similarly, farmers who live in AES5 are more likely to adopt agroforestry (wood lot) while less likely to adopt physical SWC.

The result reveals a significant wealth or liquidity constraint effect on the adoption of CSA innovations. For instance, the extent of total farm size influences the adoption of compost, physical SWC, and agroforestry. This indicates that compost, physical SWC, and agroforestry which are labour and cash intensive CSA innovations, is not adopted by resource-poor farmers because they cannot afford to hire extra labour for construction of physical SWC as well as to purchase seed for agroforestry. This is likely because wealthier farmers have both the capacity to hire extra labour and the liquidity to purchase seed for agroforestry. Similarly, the results also reveal that households who use energy saving technology such as improved cooking stove are more likely to adopt crop residue management because this technology depends on the crop residue from production and most of the time used for cocking food. Environmentally, this paper finding that climate change risk perception of increasing trend of temperature and hailstorm enhances adoption of CSA innovations ( crop residue management, physical SWC, and agroforestry concurs with the finding of (Fagariba et al., 2018) who reported that, among other factors high temperature and evaporation highly influenced farmers' ability to adapt to climate change because crop residue management and physical SWC can limit nutrient leaching, decrease raindrop impact, protect the soil from water and wind erosion. 
Table 4

Selection (logit) model result of CSA innovations

\begin{tabular}{|c|c|c|c|c|}
\hline Explanatory variables & Crop residue management & Compost & Physical SWC & Agroforestry \\
\hline Education & $0.31(0.1)^{\star \star \star}$ & $-0.02(0.1)$ & $0.21(0.09)^{\star \star}$ & $0.2(0.11)^{\star}$ \\
\hline Farm experience & $-0.01(0.01)$ & $-0.01(0.01)$ & $0.01(0.01)$ & $0.01(0.01)$ \\
\hline Climate Change awareness & $0.09(0.28)$ & & $-0.94(0.31)^{\star \star \star}$ & $-0.39(0.33)$ \\
\hline CSA awareness & $0.55(0.29) *$ & $0.78(0.22)^{\star \star \star}$ & $0.7(0.3)^{\star \star}$ & $0.78(0.3)^{\star \star \star}$ \\
\hline Total farm size & $0.14(0.13)$ & $0.32(0.15)^{\star \star}$ & $0.22(0.13)^{\star}$ & $0.39(0.18)^{\star \star}$ \\
\hline Number of Plots & $-0.09(0.05)^{\star}$ & $0.01(0.06)$ & $-0.04(0.05)$ & $0.07(0.06)$ \\
\hline Livestock holding & $0.01(0.03)$ & $0.05(0.03)$ & $0.03(0.03)$ & $-0.02(0.03)$ \\
\hline Access to credit & $-0.12(0.16)$ & $-0.01(0.17)$ & $0.27(0.15)^{\star}$ & $0.01(0.19)$ \\
\hline Access to saving & $0.04(0.2)$ & & $0.29(0.19)$ & $0.24(0.25)$ \\
\hline Access to extension service & $-0.23(0.09)^{\star \star \star}$ & $0.09(0.11)$ & $0.25(0.08)^{\star \star \star}$ & $-0.21(0.11)^{\star}$ \\
\hline Access to communication & & & $0.23(0.15)$ & $-0.09(0.18)$ \\
\hline Long distance to market & $0.08(0.1)$ & $0.29(0.1)^{\star \star \star}$ & $0.02(0.09)$ & $0.11(0.11)$ \\
\hline Access to energy & $0.51(0.16)^{\star \star \star}$ & $0.57(0.17)^{\star \star \star}$ & $0.52(0.15)^{\star \star \star}$ & $0.19(0.19)$ \\
\hline Access to water(stand pipe) & $0.42(0.18)^{\star \star}$ & $0.08(0.21)$ & $0.12(0.18)$ & $0.02(0.21)$ \\
\hline Access to water (Tube well) & $0.58(0.2)^{\star \star \star}$ & $-0.23(0.21)$ & $-0.32(0.19)$ & $-0.1(0.22)$ \\
\hline Community work & $0.25(0.17)$ & & $0.09(0.17)$ & $0.04(0.2)$ \\
\hline Wenfel & & $-0.43(0.17)^{\star \star}$ & $-0.28(0.16)^{\star}$ & $0.17(0.19)$ \\
\hline Informal aid support & $0.04(0.03)$ & $-0.01(0.04)$ & $-0.03(0.03)$ & $0.02(0.03)$ \\
\hline Strong tenure security & $0.39(0.17)^{\star \star}$ & $0.22(0.19)$ & $0.03(0.17)$ & $0.53(0.23)^{\star \star}$ \\
\hline Poor soil fertility & $-0.28(0.19)$ & $-0.39(0.21)^{\star}$ & $-0.03(0.19)$ & $0.46(0.23)^{\star \star}$ \\
\hline Slope of the farm land & $1.21(0.45)^{\star \star \star}$ & $1.14(0.44)^{\star \star}$ & $0(0.42)$ & $0.09(0.69)$ \\
\hline Temperature increased & $0.49(0.18)^{\star \star \star}$ & $-0.09(0.19)$ & $0.27(0.17)$ & $0.48(0.22)^{\star \star}$ \\
\hline Precipitation decreased & $0(0.16)$ & $-0.11(0.18)$ & $-0.19(0.16)$ & $-0.07(0.19)$ \\
\hline Drought increased & $-0.16(0.17)$ & $-0.12(0.19)$ & $-0.14(0.16)$ & $0.09(0.19)$ \\
\hline Flood increased & $0.13(0.16)$ & $0.06(0.17)$ & $0.03(0.15)$ & $0.19(0.19)$ \\
\hline Hailstorm increased & $0.41(0.16)^{\star \star}$ & $0.08(0.17)$ & $0.27(0.15)^{\star}$ & $0.19(0.19)$ \\
\hline \multirow[t]{2}{*}{ Dejen (AES1) } & & $-1.03(0.34)^{\star \star \star}$ & $0.59(0.31)^{*}$ & $-1.92(0.67) * * \star$ \\
\hline & & $-1.26(0.33)^{\star \star \star}$ & $-0.89(0.3)^{\star \star \star}$ & $-0.47(0.41)$ \\
\hline Basoliben(AES3) & $1.03(0.24)^{\star \star \star}$ & $0.57(0.33)^{*}$ & $-0.51(0.28)^{*}$ & $0.95(0.32)^{\star \star \star}$ \\
\hline Machakel(AES4) & $-0.44(0.26)^{\star}$ & & & \\
\hline Sinan (AES5) & $-0.35(0.22)$ & $-0.12(0.29)$ & $-0.42(0.24)^{\star}$ & $0.54(0.28)^{\star}$ \\
\hline Constant & $-1.59(0.63)^{\star \star}$ & $-1.38(0.73)^{\star}$ & $-1.91(0.63)^{\star \star \star}$ & $-3.5(0.84)^{\star \star \star}$ \\
\hline $\mathrm{N}$ & 422 & 422 & 422 & 422 \\
\hline Log likelihood & -1700.09 & -1721.37 & -1739.28 & -1690.54 \\
\hline Wald chi-squared & $72.76^{\star \star \star}$ & $85.58^{\star \star *}$ & $83.1^{\star \star \star \star}$ & $78.92^{\star \star \star}$ \\
\hline
\end{tabular}

The common support graphing shows that there is substantial overlap between adopters and non-adopters of crop residue management, soil and water conservation, and compost (Fig. 2). The imbalance between adopters and non-adopters of these CSA innovations were high in terms of the propensity score before matching. However, the bias was significantly reduced to below 5 percent after matching. Several variables show significant differences before the matching while after matching they are balanced. Hence, adopters and non-adopters of these CSA innovations have the same distribution in covariates after 
matching because of low pseudo $\mathrm{R}^{2}$, insignificant $\mathrm{p}$-value of the likelihood ratio test, and the mean standardized bias below 10 percent. This suggest that there is no systematic difference in the distribution of covariates between both adopter as well as non-adopter groups after matching.

Table 5 reports the estimates of the average adoption effects estimated by Nearest Neighbor Matching(NNM), Radius matching (RM), Kernel matching(KM), and Stratification matching(SM) methods. The results are reported in terms of FCS and HDDS. The result of FCS reveals that households who adopt crop residue management are more significantly food secure (p0.01) than non-adopters. For crop residue management adopter household's food consumption score has increased by 5.62, 8.46, 7.69, and 7.3 for matching algorithm of NNM, RM, KM, and SM methods compared to non-adopters (Table 5). This results are consistent with (Mupangwa et al., 2019), who reported that crop residue management enhances food security and agricultural productivity among smallholder farmers in Zambia.

Table 5

The Effect of crop residue management on food security of the household

\begin{tabular}{|c|c|c|c|c|c|}
\hline Measure of Food security & Parameters & Nearest neighbor & Radius (0.1) & Kernel ${ }^{a}$ & Stratification \\
\hline \multirow[t]{4}{*}{ FCS for crop residue management } & ATT & $5.62(1.79)$ & $8.46(1.4)$ & $7.69(2.1)$ & $7.3(1.67)$ \\
\hline & Treated & 190 & 190 & 190 & 190 \\
\hline & Untreated & 80 & 220 & 220 & 220 \\
\hline & t-statistics & $3.15^{\star \star \star}$ & $7.43^{\star \star \star}$ & $4.73^{\star \star \star}$ & $4.36^{\star \star \star}$ \\
\hline \multirow[t]{4}{*}{ HDDS for crop residue management } & ATT & $0.4(0.136)$ & $0.276(0.115)$ & $0.323(0.1)$ & $0.337(0.122) a$ \\
\hline & Treated & 190 & 190 & 190 & 190 \\
\hline & Untreated & 162 & 221 & 221 & 221 \\
\hline & t-statistics & $2.96^{\star \star \star}$ & $2.39 \star \star$ & $3.182^{\star \star \star}$ & $2.7 * \star$ \\
\hline \multicolumn{6}{|c|}{ a: Analytical standard errors cannot be computed and bootstrap option to get bootstrapped standard errors were used. } \\
\hline \multicolumn{6}{|c|}{ Standard errors in parentheses ${ }^{*} p<0.1,{ }^{* *} p<0.05,{ }^{* *} p<0.01$} \\
\hline
\end{tabular}

Similarly, as crop residue management adopter HDDS has increased by $0.4,0.276,0.323$, and 0.337 point for matching algorithm of NNM, RM, KM, and SM methods compared to non-adopters, households who adopt crop residue management are more significantly food secure than non-adopters (p0.01). Moreover, the result of HDDS reveals that households who adopt compost and agroforestry are more significantly food secure than non-adopters ( $\mathrm{p} 0.01$ ). Compost adopter HDDS has increased by $0.462,0.4$, and 0.392 point for matching algorithm of RM, KM, and SM methods compared to non-adopters. Agroforestry adopter HDDS has increased by $0.4,0.404$, and 0.446 point for matching algorithm of RM, KM, and SM methods compared to non-adopters (Table 6).

Table 6

Effect of compost and agroforestry on food security of the household

\begin{tabular}{|c|c|c|c|c|c|}
\hline Measure of Food security & Parameters & Nearest neighbor & Radius (0.1) & Kernel a & Stratification \\
\hline \multirow[t]{4}{*}{ HDDS of Compost } & ATT & $0.19(0.147)$ & $0.462(0.11)$ & $0.4(0.14)$ & $0.392(0.125)$ \\
\hline & Treated & 279 & 279 & 279 & 279 \\
\hline & Untreated & 124 & 142 & 142 & 142 \\
\hline & t-statistics & 1.295 & $4.569 * \star \star$ & $2.85^{\star \star \star}$ & $3.142^{\star \star \star}$ \\
\hline \multirow[t]{4}{*}{ HDDS of Agroforestry } & ATT & $0.103(0.204)$ & $0.4(0.166)$ & $0.404(0.169$ & $0.446(0.17)$ \\
\hline & Treated & 87 & 87 & 87 & 87 \\
\hline & Untreated & 65 & 258 & 258 & 258 \\
\hline & t-statistics & 0.506 & $2.406 * \star$ & $2.39 * \star$ & $2.629 * \star$ \\
\hline
\end{tabular}

On the contrary, households who adopt physical SWC are significantly less food secure than non-adopters (p0.01) as physical SWC adopter household's FCS decreased by $-6.3,-5.1,-5.44$, and -5.9 point for matching algorithm of NNM, RM, KM, and SM methods compared to non-adopters (Table 7). Although this result is differ from some literatures that report the positive effect of SWC for enhancing food security (Zougmoré et al., 2014), this result is also consistent with the research (Akalu et al., 2013) who reported volatility of profit of the SWC/ practice in smallholder agriculture. In addition, previous research in Ethiopia (Kassie et al. 2008) has also shown that stone bunds are more productive in drier areas than in wetter areas consistent with our study area which receives more than $2000 \mathrm{~mm}$ of precipitation annually. However, physical SWC might not be profitable from a private-economic point of view yet it may be profitable at watershed level (Akalu et al., 2013). 
Table 7

Effect of physical SWC on food security of the household

\begin{tabular}{|c|c|c|c|c|c|}
\hline Measure of Food security & Parameters & Nearest neighbor & Radius (0.1) & Kernel a & Stratification \\
\hline \multirow[t]{4}{*}{ FCS of physical SWC } & ATT & $-6.29(1.82)$ & $-5.1(1.2)$ & $-5.44(1.1)$ & $-5.91(1.2)$ \\
\hline & Treated & 214 & 214 & 214 & 214 \\
\hline & Untreated & 90 & 189 & 189 & 189 \\
\hline & t-statistics & 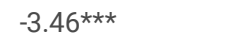 & $-4.31^{\star \star \star}$ & $-5.02 * \star \star$ & $-5.15^{\star \star \star}$ \\
\hline
\end{tabular}

Since estimating the magnitude of selection bias with non-experimental data is not possible, the study addressed this problem through a method Rosenbaum bounds sensitivity analysis (Rosenbaum \& Rubin, 2006). Hence, the test showed that matching estimators are robust against hidden bias for crop residue management, soil and water conservation, compost, and agroforestry (Annex C Table 1, 2, 3 and 4).

\subsection{Endogenous switching regression (ESR) estimation results}

Endogenous switching regression (ESR) analysis was conducted to measure the impact of CSA innovations adoption on the food security to control selection bias and effect of unobserved variables. The ESR analysis used a more rigorous estimation method by employing the full information maximum likelihood (FIML) than simple ML estimation method that involves an adoption equation and separate outcome equations for adopters and non-adopters of CSA innovations, which are estimated simultaneously.

The FIML results of FCS of CSA innovations the first column shows the food security model for adopters and non-adopters of crop residue management and physical SWC. The estimated correlation coefficient between adopters and non-adopters of crop residue management and physical SWC versus food security are rho1 and rho2 respectively.

The estimated correlation coefficient between adopters and non-adopters of crop residue management and physical SWC versus food security are rho 1 and rho 2 respectively. The estimated correlation coefficients rho 1 and rho 2 are negative and significantly different from zero, indicating self-selection bias among crop residue management adopters and non-adopters, as well as physical SWC adopters and non-adopters. Thus, this result suggests that both observed and unobserved factors influence the decision to adopt crop residue management and physical SWC as well as the food security. The significance of the likelihood ratio tests for independence of equations also indicates that there is joint dependence between the crop residue management and physical SWC adoption equation and the food security equations for adopters and non-adopters. Thus, we can obtain simultaneous solution for the two equations.

The estimated correlation coefficients rho1 and rho2 of crop residue management are negative and significantly different from zero, indicating self-selection bias among crop residue management adopters and non-adopters while rho1 and rho2 are negative and significantly different from zero for compost and agroforestry which shows indicating self-selection bias among compost adopters and agroforestry non-adopters, respectively. Thus, this result suggests that both observed and unobserved factors influence the decision to adopt crop residue management, compost, and agroforestry as well as the food security. The significance of the likelihood ratio tests for independence of equations also indicates that there is joint dependence between the crop residue management, compost, and agroforestry adoption equation and the food security equations for adopters and non-adopters. Thus, we can obtain solution for the two equations simultaneously.

\section{Determinants of FCS and HDDS among adopters and non-adopters of CSA innovations}

The results on the determinants ${ }^{1}$ of FCS and HDDS among adopters and non-adopters are shown in Table 8 . The findings show that education has a negative and statistically significant impact on the FCS of non-adopters of crop residue management. This shows that education plays a significant role in buffering against reduced food security among of adopters of crop residue management. Farming experience has a negative and statistically significant impact on the FCS of non-adopters of physical SWC. This demonstrates that farming experience has a buffering effect against reduced food security among adopters of physical SWC. Education and farm experience are the two important determinants of food security among adopters of crop residue management as well as physical SWC.

Total farm size and number of cultivated plots have a positive and statistically significant impact on FCS of adopters of crop residue management. This shows that farmers who have larger farm size and number of plots may benefit more by adopting crop residue management. The finding is concurrent with (G. Belay et al., 2017) that reported that bigger farm size accrues benefits of economies of scale to farmers and also provide a means of diversifying production.

Distance to market has a positive and significant impact on the FCS of adopters of crop residue management while a negative and significant impact on nonadopters of crop residue management. Framers who are far from market are more benefited through increased food security if they adopt crop residue management than otherwise. This is may be due to the complementarity effect of crop residue management on chemical fertilizer that reduces the amount of chemical fertilizer used and the cost associated with it which can be used to buy more food from market. Whereas, distance to market has a negative and significant impact on the FCS of adopters of physical SWC. Adoption of efficient energy technology has a negative and significant impact on the FCS of both adopters and non-adopters of crop residue management and physical SWC. Hence, adopting of efficient energy technology does not have any impact on the 
FCS of the household. Hence, longer distance has a positive effect on FCS of adopters of crop residue management and physical SWC. Whereas, access to water (public tap water) has a negative positive and significant effect on FCS among non-adopters of crop residue management which shows access to water buffers against reduced FCS of adopters crop residue management. 'Wenfel' has a significant and positive effect on the FCS of among non-adopters of physical SWC which shows 'Wenfel' labor sharing mechanisms hurts the adaptation strategy, adopting physical SWC, of farmers due to the increased in erratic rainfall. Some key informants said that they no longer support each other due to the erratic nature of the rainfall so they tend to focus on their farm. Informal aid support from friends and relatives has a positive and significant impact on FCS that shows borrowing has helped them when climate related climate change disaster shock occurs. Climate change risk perception of increased decreasing trend in temperature and hailstorm has buffered against reduced FCS among adopters of crop residue management that shows climate change risk perception has helped farmers to adopt crop residue management. However, climate change risk perception of drought trend increased has a negative significant effect on the FCS of both adopters and non-adopters of physical SWC which shows adoption of physical SWC does not have significant effect on farmers who believe drought has increased in the last twenty to thirty years.

Agroecosystem wise, compared to the midland with black soil agroecosystem zone (AESZ2), the midland with brown soil agroecosystem zone (AESZ3) has a negative and significant effect on the FCS of non-adopters of crop residue management which shows adoption of crop residue management has buffered against reduced FCS. The midland slopping land agroecosystem zone (AESZ4) has positive and significant effect on the FCS which shows in AES4 adoption of crop residue management does not have significant effect on FCS. The hilly and mountainous highland agroecosystem zone (AESZ5) has a positive and significant effect on the FCS of adopters of crop residue management. These demonstrate agroecosystem influences adoption of CSA innovation as well as its effect on FCS of the households. 
Table 8

Determinants of FCS among adopters and non-adopters of CSA innovations

\begin{tabular}{|c|c|c|c|c|}
\hline \multirow[t]{2}{*}{ Explanatory variables } & \multicolumn{2}{|c|}{ Crop residue management } & \multicolumn{2}{|l|}{ Physical SWC } \\
\hline & Adopter's & Non-adopter's & Adopter's & Non-adopter's \\
\hline \multicolumn{5}{|l|}{ Socio-demographic factors } \\
\hline Education & $-0.79(0.87)$ & $-2.73(1.06)^{\star \star}$ & $-0.79(1.03)$ & $0.21(0.98)$ \\
\hline Farm experience & $0.01(0.09)$ & $-0.01(0.09)$ & $-0.09(0.1)$ & $-0.18(0.09)^{\star \star}$ \\
\hline \multicolumn{5}{|l|}{ Economic factors } \\
\hline Total farm size & $2.15(1.04)^{\star \star}$ & $-1.57(1.47)$ & & \\
\hline Number of Plots & $0.89(0.46)^{*}$ & $0.46(0.52)$ & $0.85(0.53)$ & $0.42(0.48)$ \\
\hline Livestock holding & $-0.26(0.22)$ & $-0.21(0.31)$ & $-0.39(0.27)$ & $0.07(0.25)$ \\
\hline \multicolumn{5}{|l|}{ Institutional factors } \\
\hline Distance to market & $1.86(0.92)^{\star \star}$ & $-3.08(0.91)^{\star \star \star}$ & $-1.78(0.95)^{\star}$ & $-0.69(1.02)$ \\
\hline Access to energy & $-3.28(1.7)^{\star}$ & $-5.42(1.61)^{\star \star \star}$ & $-4.37(1.87)^{\star \star}$ & 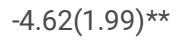 \\
\hline Access to water (Stand pipe) & $0.48(1.93)$ & $-7.28(1.84)^{\star \star \star}$ & & \\
\hline Access to water (Tube well ) & $0.75(1.85)$ & $1.41(1.92)$ & & \\
\hline Wenfel & & & $1.39(1.75)$ & $3.98(1.59)^{\star \star}$ \\
\hline Informal aid support & $0.26(0.32)$ & $0.28(0.3)$ & $1.02(0.33)^{\star \star \star}$ & $0.24(0.34)$ \\
\hline \multicolumn{5}{|l|}{ Environmental factors } \\
\hline Poor soil fertility & $2.91(1.8)$ & $0.36(1.79)$ & $-1.78(1.99)$ & $1(2.07)$ \\
\hline Temperature increased & $-2.92(1.89)$ & $-3.96(1.63)^{\star \star}$ & & \\
\hline Precipitation decreased & $1.77(1.51)$ & $-0.67(1.57)$ & $1.66(1.61)$ & $-1.76(1.68)$ \\
\hline Drought increased & $-1.64(1.56)$ & $-2.19(1.6)$ & $-3.57(1.68)^{\star \star}$ & $-2.8(1.64)^{\star}$ \\
\hline Hailstorm increased & $-1.65(1.43)$ & $-6.14(1.54)^{\star \star \star}$ & $1.05(1.54)$ & $1.31(1.64)$ \\
\hline Flood increased & $-0.3(1.34)$ & $2.19(1.61)$ & & \\
\hline \multicolumn{5}{|l|}{ Agroecosystem zones } \\
\hline Midland with brown soil (AES3) & $0.69(2.37)$ & $-9.47(2.79)^{\star \star \star}$ & & \\
\hline Midland with slopping land (AES4) & $6.03(2.48)^{\star \star}$ & 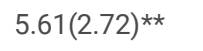 & & \\
\hline Hilly and mountainous highland (AES5) & $7.46(2.1)^{\star \star \star}$ & $2.65(2.36)$ & & \\
\hline Constant & $30.4(7.16)^{\star \star \star}$ & $55.2(5.35)^{\star \star \star}$ & $49.99(6.3)^{\star \star \star}$ & 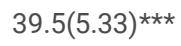 \\
\hline Ins1 & $2.15(0.06)^{\star \star \star}$ & & $2.4(0.08)^{\star \star \star}$ & \\
\hline Ins2 & $2.43(0.09)^{\star \star \star}$ & & $2.43(0.09)^{\star \star \star}$ & \\
\hline rho1 & $0.14(0.28)$ & & $-0.51(0.20)^{\star \star}$ & \\
\hline rho2 & $-0.94(0.06)^{\star \star \star}$ & & $-0.66(0.14)^{\star \star \star}$ & \\
\hline LR test of independent of equations & $13.6^{\star \star \star}$ & & $5.21 * \star \star$ & \\
\hline$N$ & 422 & & 422 & \\
\hline Log likelihood & -1718.9 & & -1818.16 & \\
\hline Wald chi-squared & $48.28 * \star \star$ & & $35.53^{\star \star \star}$ & \\
\hline
\end{tabular}

In terms of HDDS, the findings show that education has a negative and statistically significant impact on the HDDS which shows adoption of crop residue management does not have significant effect on FCS of educated farmers. Whereas, education has a positive and statistically significant effect on FCS of adopters of compost which shows educated farmers who use compost on their homestead and farm more benefit as their food security enhanced. Climate change awareness has a positive and statistically significant impact on the HDDS of adopters of crop residue management. This shows that education and 
climate change awareness plays a significant role in improving farmers' HDDS of adopters of crop residue management. As a result, education and climate change awareness influence food security among adopters of crop residue management and physical SWC.

Total farm size has a negative and statistically significant impact on the HDDS of adopters of crop residue management while the number of plots cultivated has a positive and significant effect on the HDDS of on both adopters and non-adopters of crop residue management as well as adopters of compost. The finding is concurrent with (G. Belay et al., 2017) that reported that bigger farm size in terms of diverse agro ecological setting accrues benefits of economies of scale to farmers and also provide a means of diversifying production.

Access to extension service has a positive and significant impact on HDDS of both adopters and non-adopters of crop residue management and agroforestry which shows adoption of crop residue management and agroforestry doesn't have significant effect among farmers who get frequent extension service. Similarly, participation in community watershed management program has a positive significant effect on both adopters and non-adopters of compost which shows that farmers who participate in community watershed management program enhance their HDDS whether they adopt compost or not. 'wenfel' have a positive and significant effect on the HDDS of adopters of crop residue management households. Informal support or borrowing has helped the non-adopters of compost than adopters during climate change shocks. Hence, adoption of compost has buffered against borrowing during climate change shocks. Poor soil fertility has a negative and significant effect on the HDDS of non-adopters agroforestry which shows adoption of agroforestry has buffered against reduced HDDS of households. Climate change risk perception of increased hailstorm has negative and significant impact on HDDS of both adopters and nonadopters of crop residue management. However, Climate change risk perception of increased hailstorm has negative and significant effect on adopters of compost while non-adopters of agroforestry. This shows that the increased hailstorm did not buffer against reduced HDDS even if they adopted compost while buffered against reduced HDDS among adopters of agroforestry.

Agroecosystem wise, the low land (AES1) has negative and significant impact on HDDDS of both adopters and non-adopters of compost while the midland with brown soil agroecosystem zone (AESZ3) has a positive and significant effect on the HDDS of non-adopters of compost. In addition, the midland with brown soil agroecosystem zone (AESZ3) has a positive and significant effect on the HDDS of adopters of crop residue management while the midland slopping land agroecosystem zone (AESZ4) and the hilly and mountainous highland agroecosystem zone (AESZ5) have positive and significant effect on the HDDS of non-adopters of crop residue management which shows in AES4 and AES5 adoption of crop residue management does not have significant effect on HDDS. These demonstrate agroecosystem influences adoption of CSA innovation and its effect on HDDS of the households (Table 9). 
Table 9

Determinants of HDDS among adopters and non-adopters of CSA innovations

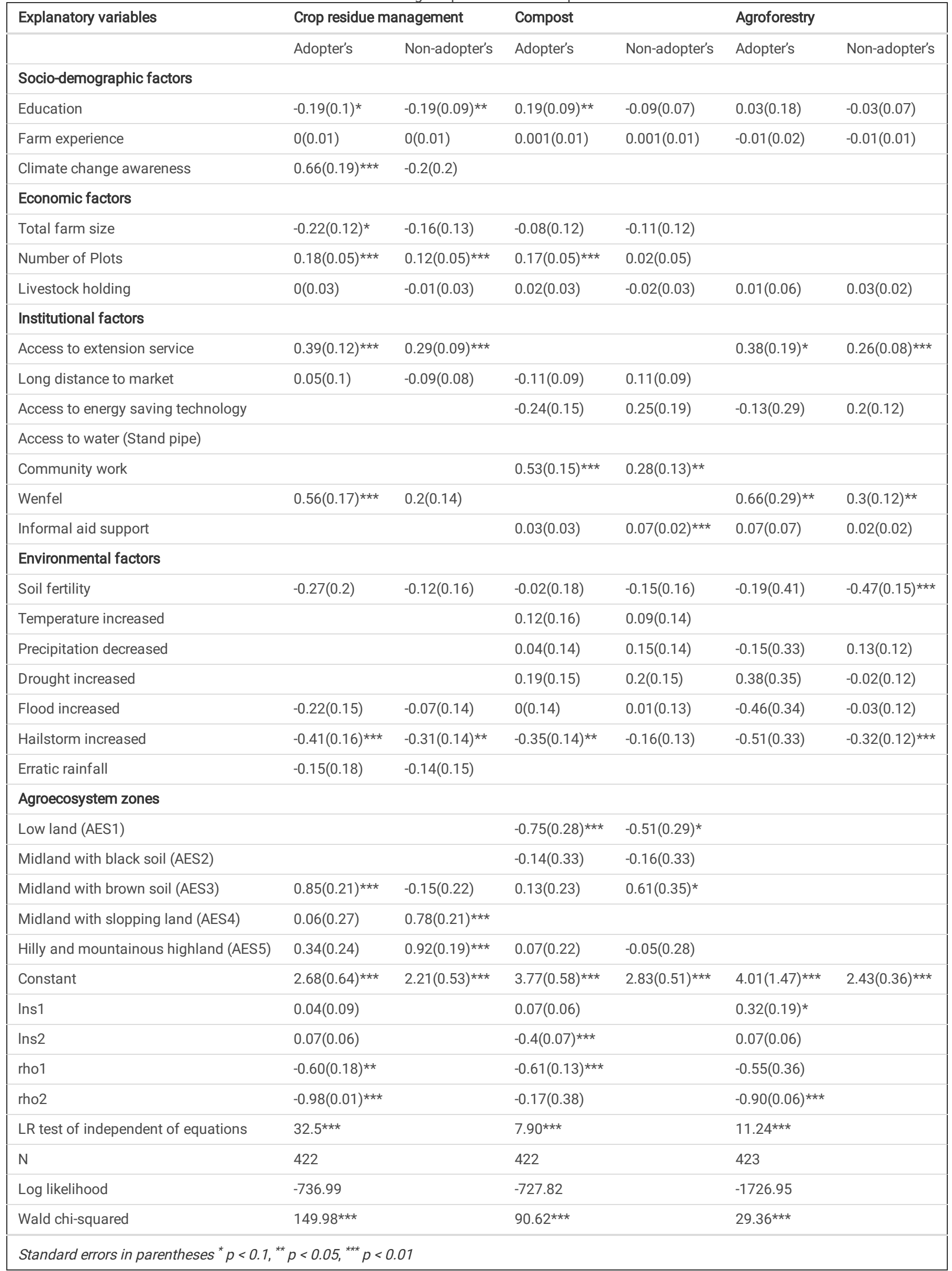


In the second stage, the least squares regression of FCS of crop residue management and physical SWC as well as crop residue management, compost and agroforestry, taking care of the selection bias correction terms from the first stage, were estimated. From the regression estimates, we derive the unconditional and conditional average effects of adoption of crop residue management, compost, physical SWC, and agroforestry. The unconditional average effect is presented in Table 10. The unconditional average effects on FCS indicate that adopters of crop residue management have higher FCS value than nonadopters whereas adopters of SWC have lower FCS value than non-adopters. Similarly, the unconditional average effects on HDDS indicate that adopters of crop residue management, compost, and agroforestry have higher FCS value than non-adopters. However, this naive comparison would drive misleading conclusions because the approach doesn't consider $t$ the difference in the outcome variable that caused by observable and unobservable characteristics.

Table 10

The Unconditional Average Effect of Adoption of CSA innovations on FCS

\begin{tabular}{|c|c|c|c|c|}
\hline CSA Innovations & $\begin{array}{l}\text { Food consumption score } \\
\text { (FCS) }\end{array}$ & $\begin{array}{l}\text { Household dietary diversity score } \\
\text { (HDDS) }\end{array}$ & $\begin{array}{l}\text { Adaptation effect (T- } \\
\text { value) }\end{array}$ & $\begin{array}{l}\text { Percent increase/ } \\
\text { decrease }\end{array}$ \\
\hline $\begin{array}{l}\text { Crop residue } \\
\text { management }\end{array}$ & $42.2(0.71)$ & & $7.4(1.02)^{\star \star \star}$ & $21.3 \%$ \\
\hline Physical SWC & $35.4(0.75)$ & & $-5.54(1.04)^{\star \star \star}$ & $-12.9 \%$ \\
\hline $\begin{array}{l}\text { Crop residue } \\
\text { management }\end{array}$ & & $4.1(0.09)$ & $0.35(0.11)^{\star \star \star}$ & $9.5 \%$ \\
\hline Compost & & $4.1(0.07)$ & $0.49(0.11)^{\star \star \star}$ & $13.6 \%$ \\
\hline Agroforestry & & $4.4(0.15)$ & $0.63(0.13)^{\star * *}$ & $16.6 \%$ \\
\hline
\end{tabular}

Table 11 presents the true average adoption effects (ATE) of FCS under actual and counterfactual conditions. In this table, the food consumption score variable of farm households who adopted the crop residue management, compost, physical SWC, and agroforestry were compared with the outcome variables that would have been found if the households had not adopted. In order to determine the average adoption effects, we compare Columns A and B of Table 9. Column C presents the impacts of adoption of CSA innovation on food consumption score, computed as the difference between the above columns.

Table 11

Average Expected FCS and HDDS with Adoption Effects of CSA innovations

\begin{tabular}{|c|c|c|c|c|c|}
\hline $\begin{array}{l}\text { CSA } \\
\text { innovations }\end{array}$ & $\begin{array}{l}\text { Actual FCS if farm } \\
\text { households did adopt } \\
\text { (A) }\end{array}$ & $\begin{array}{l}\text { Counterfactual FCS if farm } \\
\text { households didn't adopt } \\
\text { (B) }\end{array}$ & $\begin{array}{l}\text { Actual HDDS if farm } \\
\text { households did adopt } \\
\text { (A) }\end{array}$ & $\begin{array}{l}\text { Counterfactual HDDS if farm } \\
\text { households didn't adopt } \\
\text { (B) }\end{array}$ & $\begin{array}{l}\text { Adoption } \\
\text { Effects } \\
\text { (C) }\end{array}$ \\
\hline \multirow[t]{2}{*}{$\begin{array}{l}\text { Crop residue } \\
\text { management }\end{array}$} & $42.2(0.4)$ & $19.5(0.5)$ & $4.1(0.065)$ & $1.9(0.03)$ & $\begin{array}{l}\text { ATT of FCS = } \\
22.6(0.6)^{* \star *}\end{array}$ \\
\hline & & & & & $\begin{array}{l}\text { ATT of HDDS= } \\
2.2(0.07)^{\star \star \star}\end{array}$ \\
\hline SWC & $35.5(0.4)$ & $33.2(0.4)$ & & & $\begin{array}{l}\text { ATT }= \\
2.3(0.57)^{\star \star \star}\end{array}$ \\
\hline Compost & & & $4.1(0.04)$ & $3.8(0.03)$ & $\begin{array}{l}\text { ATT }= \\
0.28(0.05)^{\star \star *}\end{array}$ \\
\hline Agroforestry & & & $4.4(0.07)$ & $2.3(0.06)$ & $\begin{array}{l}\text { ATT }= \\
2.12(0.1)^{\star \star \star}\end{array}$ \\
\hline
\end{tabular}

Compared to non-adoption, on the actual adoption of crop residue management, compost, and agroforestry has increased the food security of the household. Although there is scant literature of the impact of crop residue management on food security, concurrent with the current study, a literature in Mozambique showed that crop residue management with associated practices has significantly improved the food security (Mango et al., 2017). Literature that assess the impact of SWC practices in Ethiopia shows that physical SWC practices were effective in reducing surface run-off and nutrient loss, and controlling soil erosion (Akalu et al., 2013; Desalew M. \& Aklilu A., 2017; Simeneh \& Fisseha, 2016; Woldeamlak Bewekt, 2007). However, studies have shown that the impacts of SWC practices on crop yield and the economic viability of SWC practices were inconsistent and results were site-specific (Adimassu et al., 2017). For instance, construction of SWC practices such as soil and stone bunds reduced crop yield for the first few years (Adimassu et al., 2014; Kassie et al., 2011) while increased crop yields on terraced fields for teff, barley and maize has increased (Adgoa et al., 2013). Furthermore, although literature on the impact of SWC on food security is scant, concurrent with the current study result, a study in Eastern Ethiopia has discovered that adoption of soil and water conservation not only positively impacts the per capita food consumption expenditure and net crop value but also significantly reduces the probability of farmers being food insecure (Sileshi et al., 2019) 
${ }^{1}$ The determinants of adoption result of the ESR estimation for all outcome variables are not reported here because the estimates are not different from those presented in Table 7.

\section{Conclusion And Recommendation}

CSA innovations sustainably insure food and nutrition security through enhanced quantity and quality food production system. This paper tried to examine the determinates and impact of CSA innovations of on food and nutrition security among smallholder farmers in the Upper Blue Nile Highlands of Ethiopia. The study used 424 households from the five selected agroecosystems of the Upper Blue Nile Highlands of Ethiopia and employed propensity score matching and endogenous switching regression estimation models. The sample showed that 31, 48, and 21 percent of the households were food secure, borderline, and food insecure respectively. The result showed that adoption of CSA innovations significantly affects household food and nutrition security. Crop residue management, compost, physical soil and water conservation (SWC), and agroforestry increases household food and nutrition security. Education, climate change and CSA awareness, total farm size, number of plots cultivated, access to credit, access to extension, long distance to market, access to energy saving technology, access to water infrastructure, social network ('wenfel' participation), strong tenure security, poor soil fertility, slope of farm land, and climate change risk perception of increasing trend in temperature and hailstorm as well as agroecosystem zone determine adoption of different CSA innovations. Education, climate change awareness, total farm size, access to extension services, access to water infrastructure, social network, soil fertility, climate change risk perceptions, and agroecosystem zones determine the food security of adopters of CSA innovations. Economic, institutional and environmental factors determine adoption as well as the household food and nutrition. Food and nutrition security can be strengthened through a policy that scale up rural primary education, climate change awareness and its associated climate change risk perception, strengthen access to extension service, and access to water infrastructure.

\section{Declarations}

\section{Ethics approval and consent to participate}

Not applicable

\section{Consent for publication}

Not applicable

\section{Availability of data and materials}

Please contact the author for data requests.

\section{Competing interests}

The authors declare that they have no conflict of interests.

\section{Funding}

The authors would like to thank Addis Ababa University (AAU) and National Science Foundation (NSF) for providing financial support for the data collection and write-up of the manuscript.

\section{Authors' contributions}

* The first author (AT) generated the idea, designed the study, designed data collection instruments, carried out the data collection and analyzed the data, and wrote the manuscript. The second, and the third authors, (BS and MB) study design, shaped the data collection instruments, technically supported the data analysis process, revised and commented on the draft manuscript. All authors read and approved the final manuscript

\section{Acknowledgments}

We want to thank the farmers, agricultural development agents, and local administrators of the study area for their assistance during the fieldwork. We are also grateful to Addis Ababa University (AAU) for providing the required facilities for the data analysis and write-up of this paper.

\section{References}

1. Adgoa, E., Teshomec, A., \& Mati, B. (2013). Impacts of long-term soil and water conservation on agricultural productivity: The case of Anjenie watershed, Ethiopia. Agricultural Water Management, 117, 55-61. https://doi.org/10.1016/j.agwat.2012.10.026

2. Adhikari, U., Nejadhashemi, A. P., \& Woznicki, S. A. (2015). Climate change and eastern Africa: a review of impact on major crops. Food and Energy Security, 4(2), 110-132. https://doi.org/10.1002/fes3.61

3. Adimassu, Z., Langan, S., Johnston, R., Mekuria, W., \& Amede, T. (2017). Impacts of Soil and Water Conservation Practices on Crop Yield, Run-off, Soil Loss and Nutrient Loss in Ethiopia: Review and Synthesis. Environmental Management, 59(1), 87-101. https://doi.org/10.1007/s00267-016-0776-1

4. Adimassu, Z., Mekonnen, K., Yirga, C., \& Kessler, A. (2014). Effect of soil bunds on runoff, soil and nutrient losses, and crop yield in the central highlands of ethiopia. Land Degradation and Development, 25(6), 554-564. https://doi.org/10.1002/ldr.2182 
5. Akalu, T., Rolker, D., \& Graaff, J. de. (2013). Financial viability of soil and water conservation technologies in northwestern Ethiopian highlands. Applied Geography, 37(1), 139-149. https://doi.org/10.1016/j.apgeog.2012.11.007

6. Alem, K., Kibebew, K., Jemma, H., Muktar, M., \& Yosef, A. (2016). Farmers perception towards climate change and their adaptation measures in Dire Dawa Administration, Eastern Ethiopia. Journal of Agricultural Extension and Rural Development, 8(12), 269-283. https://doi.org/10.5897/JAERD2016.0800

7. Alomia-Hinojosa, V., Speelman, E. N., Thapa, A., Wei, H.-E., McDonald, A. J., Tittonell, P., \& Groot, J. C. J. (2018). Exploring farmer perceptions of agricultural innovations for maize-legume intensification in the mid-hills region of Nepal. International Journal of Agricultural Sustainability, 16(1), 74-93. https://doi.org/10.1080/14735903.2018.1423723

8. Arslan, A., McCarthy, N., Lipper, L., Asfaw, S., Cattaneo, A., \& Kokwe, M. (2015). Food security and adaptation impacts of potential climate smart agricultural practices in Zambia (Issue January). http://www.fao.org/3/a-i4365e.pdf

9. Asfaw, S., Battista, F. Di, \& Leslie, L. (2014). Food security impact of agricultural technology adoption under climate change: micro-evidence from Niger. In ESA Working Paper (No. 14-12; Issue 14).

10. Asfaw, S., Manuela, C., \& Lipper, L. (2015). Adaptation to climate risk and food security: Evidence from smallholder farmers in Ethiopia. In FAO (Issue February). file:///Articles/2015/Asfaw/FAO 2015 Asfaw-2.pdf

11. Asmare, F., Teklewold, H., \& Mekonnen, A. (2019). The effect of climate change adaptation strategy on farm households welfare in the Nile basin of Ethiopia. International Journal of Climate Change Strategies and Management, 11(4), 518-535. https://doi.org/10.1108/IJCCSM-10-2017-0192

12. Bachewe, F. N., Berhane, G., Minten, B., \& Taffesse, A. S. (2018). Agricultural Transformation in Africa? Assessing the Evidence in Ethiopia. World Development, 105, 286-298. https://doi.org/https://doi.org/10.1016/j.worlddev.2017.05.041

13. Baudron, F., Delmotte, S., Corbeels, M., Herrera, J. M., \& Tittonell, P. (2014). Multi-scale trade-off analysis of cereal residue use for livestock feeding vs. soil mulching in the Mid-Zambezi Valley, Zimbabwe. Agricultural Systems. https://doi.org/10.1016/j.agsy.2014.03.002

14. Belay, K., \& Winfried M.,. (2004). Access to rural land in Eastern Ethiopia: Mismatch between policy and reality. Journal of Agriculture and Rural Development in the Tropics and Subtropics, 105(2), 123-138.

15. Belay, G., Mohammadi, H., Ardalan, A., \& Bavani, A. (2017). Climate Change Intervention and Adatation in Ethopia: A Critical Appraisal of Sustematic Review. Iranian Journal of Health. http://www.ijhse.ir/index.php/IJHSE/article/view/244

16. Belay, T., Hengsdijk, H., Ro"tter, R., Kahiluoto, H., Senthold, A., \& Ittersum, M. Van. (2013). Adapting to Climate Variability and Change: Experiences from Cereal-Based Farming in the Central Rift and Kobo Valleys ,. Environmental Management, 52, 1115-1131. https://doi.org/10.1007/s00267-013-0145-2

17. Chamberlin, J., \& Schmidt, E. (2013). Ethiopian Agriculture: A dynamic geographic perspective. Food and Agriculture in Ethiopia: Progress and Policy Challenges, 21-54. http://ebrary.ifpri.org/cdm/ref/collection/p15738coll2/id/127349

18. D., C., E., L., \& Schipper F. (2011). Adaptation to climate change in Africa: Challenges and opportunities identified from Ethiopia. Global Environmental Change, 21(1), 227-237. https://doi.org/https://doi.org/10.1016/j.gloenvcha.2010.07.013

19. Deichert, G., Gedamu, A., \& Nemomsa, B. (2017). Role of Sustainable Land Management (SLM) in Adapting to Climate Variability Through Agricultural Practices-Experiences from Ethiopian Highlands. In Climate Change Management (pp. 475-492). https://doi.org/10.1007/978-3-319-49520-0_29

20. Deressa, T., Hassan, R. M., \& Ringler, C. (2011). Assessing Household Vulnerability to Climate Change The Case of Farmers in the Nile Basin of Ethiopia. International Food and Policy Research Institute, 1-2.

21. Desalew M. \& Aklilu A. (2017). Determinants of farmers' perception to invest in soil and water conservation technologies in the North-Western Highlands of Ethiopia. International Soil and Water Conservation Research, 5(1), 56-61. https://doi.org/10.1016/j.iswcr.2017.02.003

22. Di Falco, S., \& Veronesi, M. (2013). How can African agriculture adapt to climate change? A counterfactual analysis from Ethiopia. Land Economics, 89(4), 743-766. https://doi.org/10.2139/ssrn.2030220

23. Diallo, A., Donkor, E., \& Owusu, V. (2020). Climate change adaptation strategies, productivity and sustainable food security in southern Mali. Climatic Change, 159(3), 309-327. https://doi.org/10.1007/s10584-020-02684-8

24. Dinesh, D., Frid-Nielsen, S., \& Norman, J. (2015). Is Climate-Smart Agriculture effective? In CCAFS Working Paper (No. 129). http://www.indiaenvironmentportal.org.in/files/file/ls Climate-Smart Agriculture effective.pdf

25. Duguma, L. A., Wambugu, S. W., Minang, P. A., \& van Noordwijk, M. (2014). A systematic analysis of enabling conditions for synergy between climate change mitigation and adaptation measures in developing countries. Environmental Science \& Policy, 42, 138-148.

https://doi.org/10.1016/j.envsci.2014.06.003

26. Ermias, T., Woldeamlak, B., Uhlenbrook, S., \& Wenninger, J. (2013). Understanding recent land use and land cover dynamics in the source region of the Upper Blue Nile, Ethiopia: Spatially explicit statistical modeling of systematic transitions. Agriculture, Ecosystems and Environment, 165, 98-117. https://doi.org/10.1016/j.agee.2012.11.007

27. Fagariba, C. J., Song, S., \& Baoro, S. K. G. S. (2018). Climate change adaptation strategies and constraints in Northern Ghana: Evidence of farmers in Sissala West District. Sustainability (Switzerland), 10(5). https://doi.org/10.3390/su10051484

28. FAO. (2013). Climate-Smart Agriculture: Source book. FAO. http://www.cabdirect.org/abstracts/20153237305.html

29. FDRE. (2019). Ethiopia's Climate Resilient Green Economy National Adaptation Plan.

30. Gebremicael, T. G., Mohamed, Y. A., Betrie, G. D., van der Zaag, P., \& Teferi, E. (2013). Trend analysis of runoff and sediment fluxes in the Upper Blue Nile basin: A combined analysis of statistical tests, physically-based models and landuse maps. Journal of Hydrology, 482, 57-68.

https://doi.org/10.1016/j.jhydrol.2012.12.023

31. Gebru, G. W., Ichoku, H. E., \& Phil-Eze, P. O. (2020). Determinants of smallholder farmers' adoption of adaptation strategies to climate change in Eastern Tigray National Regional State of Ethiopia. Heliyon, 6(7). https://doi.org/10.1016/j.heliyon.2020.e04356

Page 16/22 
32. Hailemariam, Alemu, Kohlin, \& D. F. (2017). Does adoption of multiple climate-smart practices improve farmers' climate resilience? Empirical evidence from the Nile basin of Ethiopia. Climate Change Economics, 8(1), 1750001. https://doi.org/10.1142/S2010007817500014

33. Hailemariam, T., Alemu, M., \& Gunnar, K. (2019). Climate change adaptation: a study of multiple climate-smart practices in the Nile Basin of Ethiopia. Climate and Development, 11(2), 180-192. https://doi.org/10.1080/17565529.2018.1442801

34. Hailemariam, T., Alemu, M., Gunnar, K., \& Salvatore, D. F. (2017). Does Adoption of Multiple Climate-Smart Practices Improve Farmers ' Climate Resilience? Climate Change Economics, 08(1).

35. Hengsdijk, H., \& Verhagen, A. (2013). Linking climate smart agriculture and good agriculture practices: case studies on consumption potatoes in South Africa, the Netherlands and Ethiopia.

http://www.researchgate.net/profile/H_Hengsdijk/publication/264346884_Linking_Climate_Smart_Agriculture_and_Good_Agricultural_Practices_Case_stu

36. IPCC. (2014). Climate Change 2014: Food Security and Food Production Systems. In Contribution of Work ing Group III to the Fifth Assessment Report of the Intergovernmental Panel on Climate Change (Issue October 2013, pp. 1-51). https://doi.org/31 March 2014

37. IPCC. (2019). Summary for Policymakers. In An IPCC Special Report on climate change, desertification, land degradation, sustainable land management, food security, and greenhouse gas fluxes in terrestrial ecosystems. Cambridge University Press.

38. Jirata, M., Grey, S., \& Kilawe, E. (2016). Ethiopia Climate-Smart Agriculture Scoping Study. FAO, Addis Abab.

39. Kassie, M., Köhlin, G., Bluffstone, R., \& Holden, S. (2011). Are soil conservation technologies " win-win?" A case study of Anjeni in the north-western Ethiopian highlands. 35, 89-99.

40. Kidane, B. Z., Hailu, M. H., \& Haile, H. T. (2017). Maize and Potato Intercropping: A Technology to Increase Productivity and Profitability in Tigray. Open Agriculture, 2(1), 411-416. https://doi.org/10.1515/opag-2017-0044

41. Komarek, A. M., Thurlow, J., Koo, J., \& De Pinto, A. (2019). Economywide effects of climate-smart agriculture in Ethiopia. Agricultural Economics (United Kingdom), 50(6), 765-778. https://doi.org/10.1111/agec.12523

42. Kosmowski, F. (2018). Soil water management practices (terraces) helped to mitigate the 2015 drought in Ethiopia. Agricultural Water Management, 204(April), 11-16. https://doi.org/10.1016/j.agwat.2018.02.025

43. Kotir, J. (2011). Climate change and variability in Sub-Saharan Africa: a review of current and future trends and impacts on agriculture and food security. Environment, Development and Sustainability, 13(3), 587-605. https://doi.org/10.1007/s10668-010-9278-0

44. Kpadonou, R. A. B., Owiyo, T., Barbier, B., Denton, F., Rutabingwa, F., \& Kiema, A. (2017). Advancing climate-smart-agriculture in developing drylands: Joint analysis of the adoption of multiple on-farm soil and water conservation technologies in West African Sahel. Land Use Policy, 61, $196-207$.

https://doi.org/10.1016/j.landusepol.2016.10.050

45. Leal Filho, W., Esilaba, A. O., Rao, K. P., \& Sridhar, G. (2015). Adapting African Agriculture to Climate Change: Transforming rural livelihoods. In Adapting African agriculture to climate change. Springer. https://doi.org/10.1007/978-3-319-13000-2

46. Lipper, L., Thornton, P. K., Campbell, B. M., Baedeker, T., Braimoh, A., Bwalya, M., Caron, P., Cattaneo, A., Garrity, D., Henry, K., Hottle, R., Jackson, L., Jarvis, A., Kossam, F., Mann, W., McCarthy, N., Meybeck, A., Neufeldt, H., Remington, T., ... Torquebiau, E. F. (2014). Climate-smart agriculture for food security. Nature Climate Change, 4(12), 1068-1072. https://doi.org/10.1038/nclimate2437

47. Lopez-Ridaura, S., Frelat, R., van Wijk, M. T., Valbuena, D., Krupnik, T. J., \& Jat, M. L. (2018). Climate smart agriculture, farm household typologies and food security: An ex-ante assessment from Eastern India. Agricultural Systems, 159(November 2017), 57-68. https://doi.org/10.1016/j.agsy.2017.09.007

48. Makate, C. (2019). Effective scaling of climate smart agriculture innovations in African smallholder agriculture: A review of approaches, policy and institutional strategy needs. In Environmental Science and Policy (Vol. 96, Issue January, pp. 37-51). Elsevier. https://doi.org/10.1016/j.envsci.2019.01.014

49. Mango, N., Siziba, S., \& Makate, C. (2017). The impact of adoption of conservation agriculture on smallholder farmers' food security in semi-arid zones of southern Africa. Agriculture \& Food Security, 6(1), 4-11. https://doi.org/10.1186/s40066-017-0109-5

50. Maxwell, D., Vaitla, B., Tesfay, G., \& Abadi, N. (2013). Resilience, Food Security Dynamics, and Poverty Traps in Northern Ethiopia Analysis of a Biannual Panel Dataset, 2011 - 2013 (Issue October).

51. Melak, M., \& Birgit, K. (2014). Food Insecurity in Ethiopia: Population, Food Production and Market. 32nd International Conference of the System Dynamics Society, 1-29.

52. Meze-hausken, E. (2004). Contrasting climate variability and meteorological drought with perceived drought and climate change in northern Ethiopia. Climate Research, 27, 19-31.

53. Miheretu, B. A. (2014). Farmers' Perception and Adoption of Soil and Water Conservation Measures: the case of Gidan Wereda, North Wello, Ethiopia. Journal of Economics and Sustainable Development, 5(24), 1-10. https://doi.org/10.1007/s10557-010-6232-1

54. Mupangwa, W., Mutenje, M., Thierfelder, C., Mwila, M., Malumo, H., Mujeyi, A., \& Setimela, P. (2019). Productivity and profitability of manual and mechanized conservation agriculture (CA) systems in Eastern Zambia. Renewable Agriculture and Food Systems, 34(5), 380-394. https://doi.org/10.1017/S1742170517000606

55. Negra, C., Vermeulen, S., Barioni, L. G., Mamo, T., Melville, P., \& Tadesse, M. (2014). Brazil, Ethiopia, and New Zealand lead the way on climate-smart agriculture. Agriculture \& Food Security, 3(1), 19. https://doi.org/10.1186/s40066-014-0019-8

56. Niang, I., Oliver, R., Mohamed, A., Amma, E., Lennard, C., Jonathan, P., \& Penny, U. (2014). Climate Change 2014: Africa. In and L. L. W. Barros, V.R., C.B. Field, D.J. Dokken, M.D. Mastrandrea, K.J. Mach, T.E. Bilir, M. Chatterjee, K.L. Ebi, Y.O. Estrada, R.C. Genova, B. Girma, E.S. Kissel, A.N. Levy, S. MacCracken, P.R. Mastrandrea (Ed.), Africa. In: Climate Change 2014: Impacts, Adaptation, and Vulnerability. Part B: Regional Aspects. Contribution of Working Group II to the Fifth Assessment Report of the Intergovernmental Panel on Climate Change (pp. 1199-1265). Cambridge University Press.

Page $17 / 22$ 
57. NMA. (2007). Climate Change National Adaptation Programme of Action (NAPA) of Ethiopia (Issue June).

58. Paulos, A., \& Belay, S. (2017). Adaptation Benefits of Climate-Smart Agricultural Practices in the Blue Nile Basin: Empirical Evidence from North-West Ethiopia. In Climate Change Adaptation in Africa. https://doi.org/10.1007/978-3-319-49520-0

59. Pender, J., \& Ehui, S. (2006). Strategies for sustainable land management in the East African highlands. In and S. E. Pender, J., F. Place (Ed.), Food Policy. International Food Policy Research Institute. http://books.google.com/books?hl=en\&amp;Ir=\&amp;id=9pzrraDIF-

wC\&amp;oi=fnd\&amp;pg=PR11\&amp;dq=Strategies+for+Sustainable+Land+Management+in+the+East+African+Highlands\&amp;ots=ddo4GR6GNT\&amF HKQ0ZgQDNA32GI

60. Rimhanen, K., Kahiluoto, H., Ketoja, E., \& Yli-halla, M. (2012). Carbon sequestration by climate smart agriculture in Ethiopia. ECosummit $2012,2012$.

61. Rosenbaum, P. R., \& Rubin, D. B. (2006). The central role of the propensity score in observational studies for causal effects. Matched Sampling for Causal Effects, 1083, 170-184. https://doi.org/10.1017/CB09780511810725.016

62. Rosenzweig, C., \& Hillel, D. (2015). Handbook of Climate Change and Agroecosystems: The Agricultural Model Intercomparison and Improvement Project (AgMIP) Integrated Crop and Economic Assessments - Joint Publication with American Society of Agronomy, Crop Science Society of America, and Soil (Vol. 3). World Scientific. https://books.google.com/books?

$\mathrm{hl}=$ en\&lr=\&id=r923CgAAQBAJ\&oi=fnd\&pg=PR7\&dq=\%22climate+smart+agriculture\%22\&ots=ZuRhMmz-ID\&sig=I8CGiUV9EITPUQqlpzHGqzrO4ak

63. Rubin, D. B. (1974). Estimating causal effects of treatments in randomized and nonrandomized studies. Journal of Educational Psychology, 66(5), 688701. https://doi.org/10.1037/h0037350

64. Samuel, G. (2006). Land, Land Policy and Smallholder Agriculture in Ethiopia: Options and Scenarios. In Future Agricultures Consortium meeting at the Institute of Development Studies 20-22 March 2006 (Issue March). http://r4d.dfid.gov.uk/Output/178530/Default.aspx

65. Samuel, O. O., \& Sylvia, T. S. (2019). Establishing the nexus between climate change adaptation strategy and smallholder farmers' food security status in South Africa: A bi-casual effect using instrumental variable approach. Cogent Social Sciences, 5(1). https://doi.org/10.1080/23311886.2019.1656402

66. Sileshi, M., Kadigi, R., Mutabazi, K., \& Sieber, S. (2019). Impact of soil and water conservation practices on household vulnerability to food insecurity in eastern Ethiopia: endogenous switching regression and propensity score matching approach. Food Security, 11(4), $797-815$. https://doi.org/10.1007/s12571-019-00943-w

67. Simane, B., \& Asrat, P. (2018). Farmers' perception of climate change and adaptation strategies in the Dabus watershed, North-West Ethiopia. Ecological Processes, 7(1). https://doi.org/10.1186/s13717-018-0118-8

68. Simane, B., Benjamin F., Z., \& Jeremy, D. F. (2016). Agroecosystem specific climate vulnerability analysis: application of the livelihood vulnerability index to a tropical highland region. Mitigation and Adaptation Strategies for Global Change, 21, 39-65. https://doi.org/10.1007/s11027-014-9568-1

69. Simane, B., Benjamin, Z., \& Mutlu, O. (2013). Agroecosystem analysis of the choke mountain watersheds, Ethiopia. Sustainability (Switzerland), 5(2), 592616. https://doi.org/10.3390/su5020592

70. Simeneh, D., \& Fisseha, G. (2016). Perception of Farmers Toward Physical Soil and Water Conservation Structures in Wyebla Watershed, Northwest Ethiopia. World Journal of Agricultural Sciences, 1(12), 57-63. https://doi.org/10.5829/idosi.ajps.2015.7.3.12822

71. Tamirat, N. (2020). Impact Analysis of Row Planting Teff Crop Technology on Household Welfare:A Case Study of Smallholder Farmers of Duna District in Hadiya Zone, Ethiopia. Journal of Economics and Sustainable Development, 11(5), 4-9. https://doi.org/10.7176/jesd/11-5-02

72. Tazeze, A., Haji, J., \& Ketema, M. (2012a). Climate Change Adaptation Strategies of Smallholder Farmers: The Case of Babilie District, East Harerghe Zone of Oromia Regional State of Ethiopia. ISSN, 3(14), 2222-1700. http://citeseerx.ist.psu.edu/viewdoc/download?doi=10.1.1.1006.3270\&rep=rep1\&type=pdf

73. Tazeze, A., Haji, J., \& Ketema, M. (2012b). Climate Change Adaptation Strategies of Smallholder Farmers: The Case of Babilie District, East Harerghe Zone of Oromia Regional State of Ethiopia. ISSN, 3(14), 2222-1700. www.iiste.org

74. Teklewold, H., Gebrehiwot, T., \& Bezabih, M. (2019). Climate smart agricultural practices and gender differentiated nutrition outcome: An empirical evidence from Ethiopia. World Development, 122, 38-53. https://doi.org/https://doi.org/10.1016/j.worlddev.2019.05.010

75. Teklewold, H., Mekonnen, A., \& Kohlin, G. (2019). Climate change adaptation: a study of multiple climate-smart practices in the Nile Basin of Ethiopia. Climate and Development, 11(2), 180-192. https://doi.org/10.1080/17565529.2018.1442801

76. Teklewold, H., Mekonnen, A., Kohlin, G., \& Di falco, S. (2017). Does adoption of multiple Climate-Smart practices improve farmers' Climate Resilience? Empirical Evidence from the Nile Basin of Ethiopia. Climate Change Economics, 08(01), 1750001. https://doi.org/10.1142/S2010007817500014

77. Teklewold, H., Tagel, G., \& Mintewab, B. (2019). Climate change adaptation: a study of multiple climate-smart practices in the Nile Basin of Ethiopia. Climate and Development, 11(2), 180-192. https://doi.org/10.1080/17565529.2018.1442801

78. Temesgen \& Rashid. (2009). Economic impact of climate change on crop production in ethiopia: Evidence from cross-section measures. Journal of African Economies, 18(4), 531. https://doi.org/10.1093/jae/ejp002

79. Tesfaye, W., \& Seifu, L. (2016). Climate change perception and choice of adaptation strategies: Empirical evidence from smallholder farmers in east Ethiopia. International Journal of Climate Change Strategies and Management, 8(2), 253-270. https://doi.org/10.1108/IJCCSM-01-2014-0017

80. Tseganeh, B., Hengsdijk, H., Ro“tter, R., Kahiluoto, H., Asseng, S., \& Ittersum, M. Van. (2013). Adapting to Climate Variability and Change: Experiences from Cereal-Based Farming in the Central Rift and Kobo Valleys ,. Environmental Management, 52(5), 1115-1131. https://doi.org/10.1007/s00267-013-0145-2

81. Tseganeh, B., Hengsdijk, H., Rötter, R., Kahiluoto, H., Asseng, S., \& Van Ittersum, M. (2013). Adapting to Climate Variability and Change: Experiences from Cereal-Based Farming in the Central Rift and Kobo Valleys, Ethiopia. Environmental Management, 52(5), 1115-1131. https://doi.org/10.1007/s00267013-0145-2

82. Tsigab, H., Diriba, D., Simane, B., \& Gebrehiwot, T. (2019). Farmers' Perceptions of Climate Change Trends and Adaptation Strategies in Semiarid Highlands of Eastern Tigray, Northern Ethiopia. Advances in Meteorology, 2019, 3849210. https://doi.org/10.1155/2019/3849210

Page $18 / 22$ 
83. Tsige, M., Synnevåg, G., \& Aune, J. B. (2020). Gendered constraints for adopting climate-smart agriculture amongst smallholder Ethiopian women farmers. Scientific African, 7. https://doi.org/10.1016/j.sciaf.2019.e00250

84. Valbuena, D., Erenstein, O., Homann-Kee Tui, S., Abdoulaye, T., Claessens, L., Duncan, A. J., Gérard, B., Rufino, M. C., Teufel, N., van Rooyen, A., \& van Wijk, M. T. (2012). Conservation \{Agriculture\} in mixed crop-livestock systems: \{Scoping\} crop residue trade-offs in \{Sub\}-\{Saharan\} \{Africa\} and $\{$ South\} $\{$ Asia\}. Field Crops Research, 132, 175-184. https://doi.org/10.1016/j.fcr.2012.02.022

85. Wekesa, B. M., Ayuya, O. I., \& Lagat, J. K. (2018). Effect of climate-smart agricultural practices on household food security in smallholder production systems: Micro-level evidence from Kenya. Agriculture and Food Security, 7(1), 1-14. https://doi.org/10.1186/s40066-018-0230-0

86. Weldegebriel, Z. B., \& Prowse, M. (2013). Climate-Change Adaptation in Ethiopia: To What Extent Does Social Protection Influence Livelihood Diversification? Development Policy Review, 31(October 2012), 35-56.

87. WFP. (2009). Comprehensive Food Security \& Vulnerability Analysis Guidelines. Africa, April, 27. https://doi.org/http://dx.doi.org/10.1016/S01698141(08)00187-X

88. WFP. (2014). Climate risk and food security in Ethiopia:

89. Woldeamlak, B., Maren, R., \& Catherine, M. (2015). Agricultural Adaptation and Institutional Responses to Climate Change Vulnerability in Ethiopia (No. 106; Issue 106). https://cgspace.cgiar.org/handle/10568/56997

90. Woldeamlak Bewekt. (2007). Soil and water conservation intervention with conventional technologies in northwestern highlands of Ethiopia: Acceptance and adoption by farmers. Land Use Policy, 24(2), 404-416. https://doi.org/10.1016/j.landusepol.2006.05.004

91. Woldeamlak, Bewket. (2012). Climate change perceptions and adaptive responses of smallholder farmers in central highlands of Ethiopia. International Journal of Environmental Studies, 69(June), 507-523. https://doi.org/10.1080/00207233.2012.683328

92. Woldeamlak, Bewket. (2001). The Need for a Participatory Approach to Soil and Water Conservation (SWC) in the Ethiopian Highlands: A Case Study in Chemoga Watershed, East Gojjam. Eastern Africa Social Science Research Review, 17(2), 43.

93. Woldeamlak, Bewket. (2013). Weed dynamics in low-input dryland smallholder conservation agriculture systems in semi-arid zimbabwe by Nester Mashingaidze Submitted in partial fulfillment of the requirements for the degree PhD Agronomy In the Faculty of Natural \& Agricultural Sciences. International Journal of Environmental Studies, 69(February), 507-523. https://doi.org/10.1080/00207233.2012.683328

94. Woldeamlak, Bewket, \& Sterk, G. (2005). Dynamics in land cover and its effect on stream flow in the Chemoga watershed, Blue Nile basin, Ethiopia. Hydrological Processes, 19(2), 445-458. https://doi.org/10.1002/hyp.5542

95. World Food Programme. (2008). Food consumption analysis - calculation and use of the food consumption score in food security analysis. In Technical Guidance Sheet. https://doi.org/10.1017/CB09781107415324.004

96. Yalew, S., Teferi, E., Van Griensven, a, Uhlenbrook, S., Mul, M., Van Der Kwast, J., \& Van Der Zaag, P. (2012). Land use change and suitability assessment in the Upper Blue Nile basin under water resources and socio-economic constraints: A drive towards a decision support system. IEMSs 2012 - Managing Resources of a Limited Planet: Proceedings of the 6th Biennial Meeting of the International Environmental Modelling and Software Society, $2124-2131$. http://www.scopus.com/inward/record.url?eid=2-s2.0-84894179758\&partnerlD=40\&md5=aa8d99368ff9ba84c59d1cacc87c37c4

97. Yesuf, M., \& Ringler, C. (2008). The Impact of Climate Change and Adaptation on Food Production in Low-Income Countries Evidence from the Nile Basin, Ethiopia. December.

98. Yibekal, T., Chanyalew, A., \& Getachew, E. (2013). Understanding the process of adaptation to climate change by small-holder farmers: the case of east Hararghe Zone, Ethiopia. Agricultural and Food Economics, 1(1), 13. https://doi.org/10.1186/2193-7532-1-13

99. Zougmoré, R., Jalloh, A., \& Tioro, A. (2014). Climate-smart soil water and nutrient management options in semiarid West Africa: a review of evidence and analysis of stone bunds and zaï techniques. Agriculture \& .... http://agricultureandfoodsecurity.biomedcentral.com/articles/10.1186/2048-7010-3-16

\section{Table}

Table 2 is not available with this version.

\section{Figures}




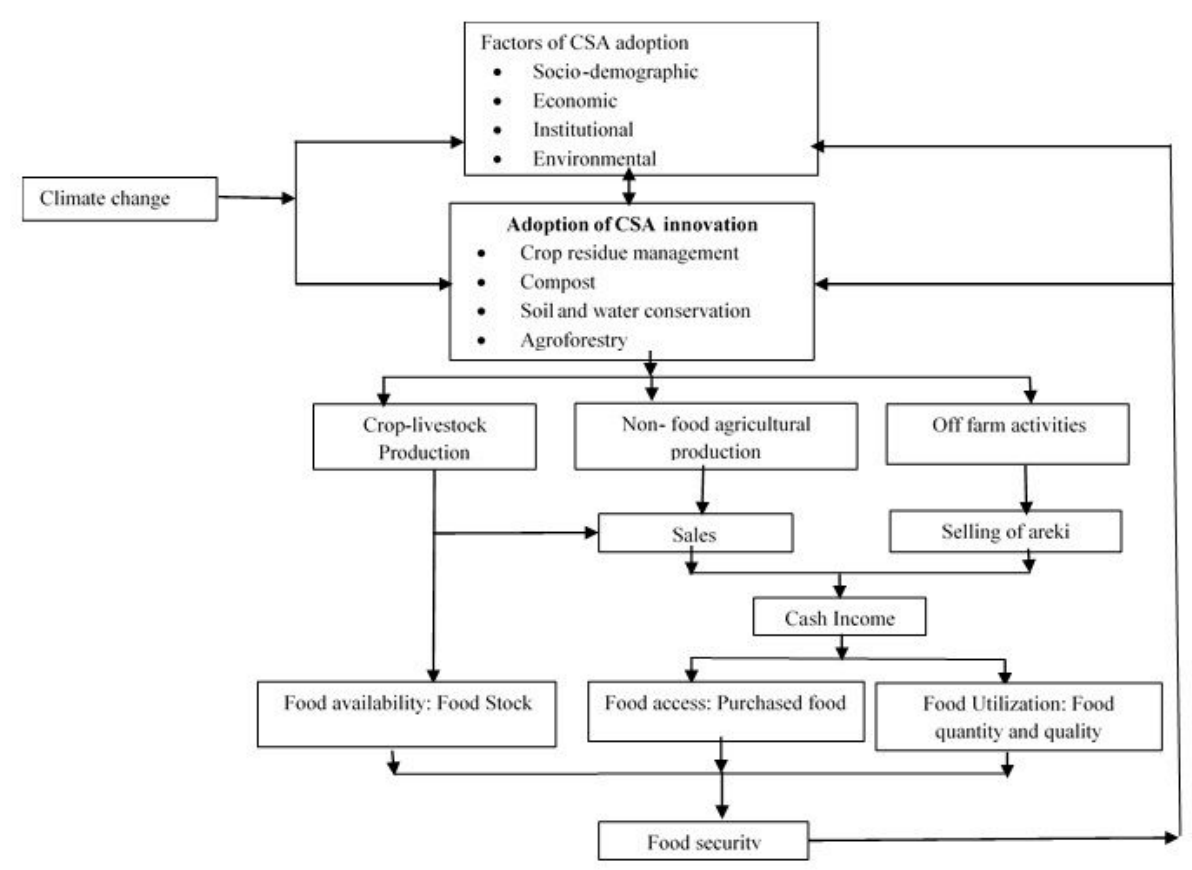

Figure 1

adoption of CSA innovation effect on household food security

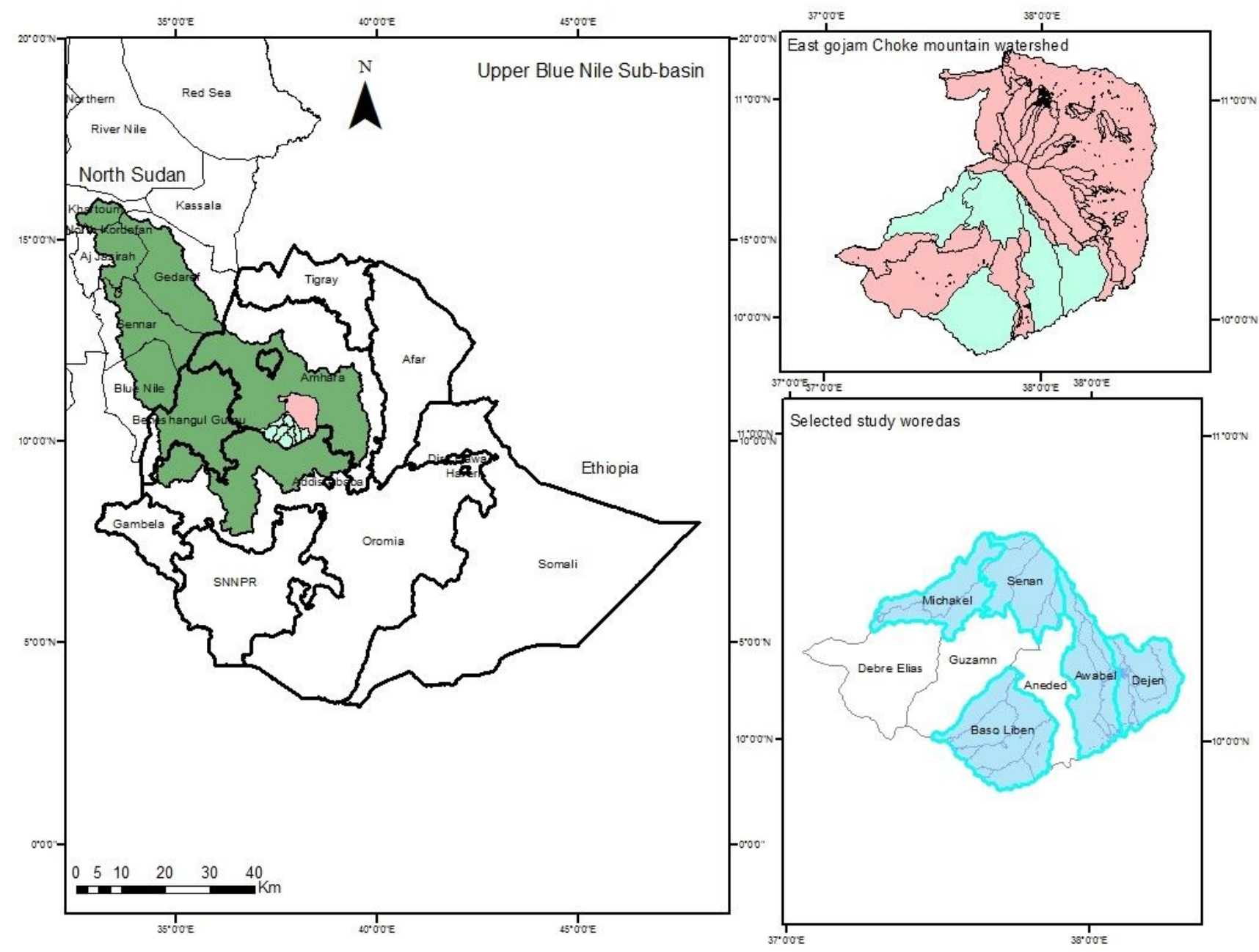

Figure 2 

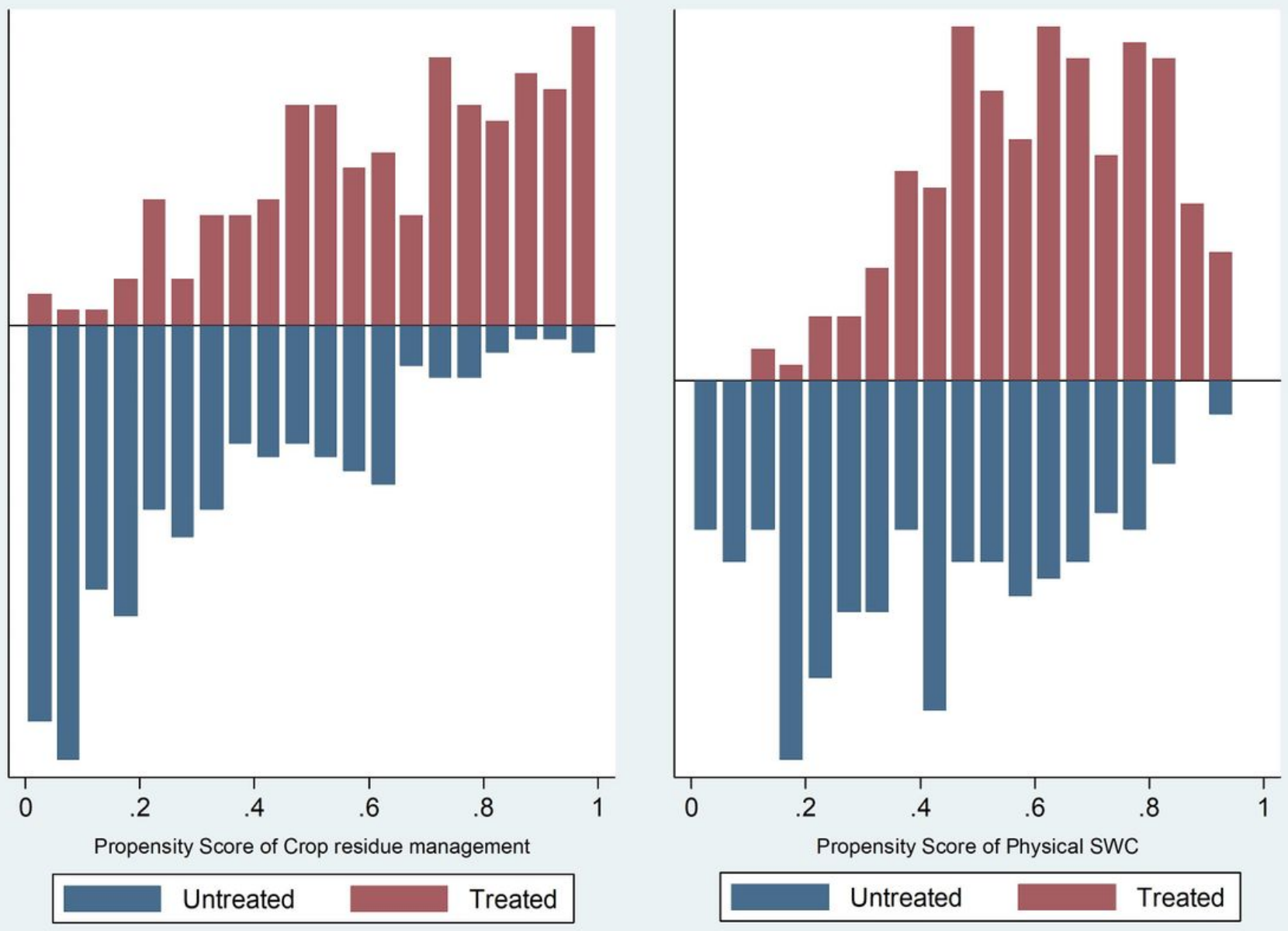

\section{Figure 3}

Common support for propensity score estimation of FCS for adoption CSA innovations. 


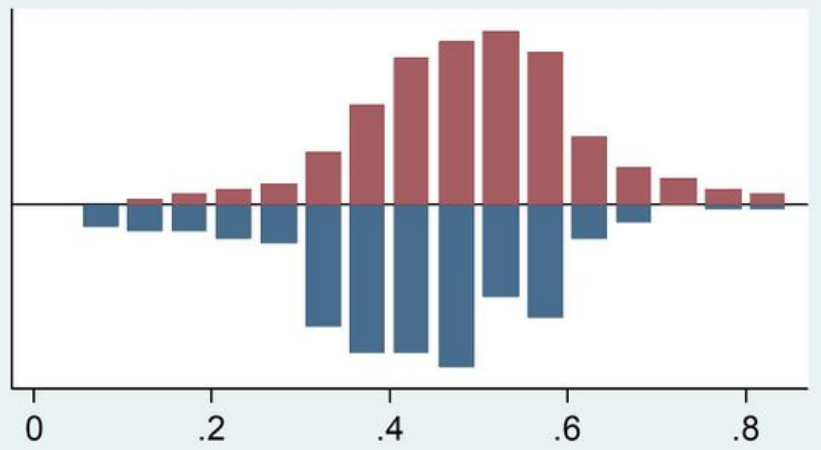

Propensity Score of HDDS for Crop residue management

Untreated Treated

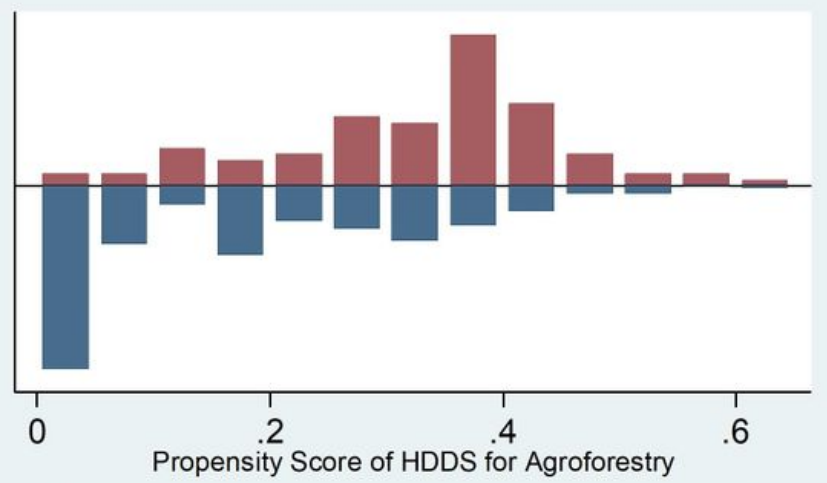

Propensity Score of HDDS for Agroforestry

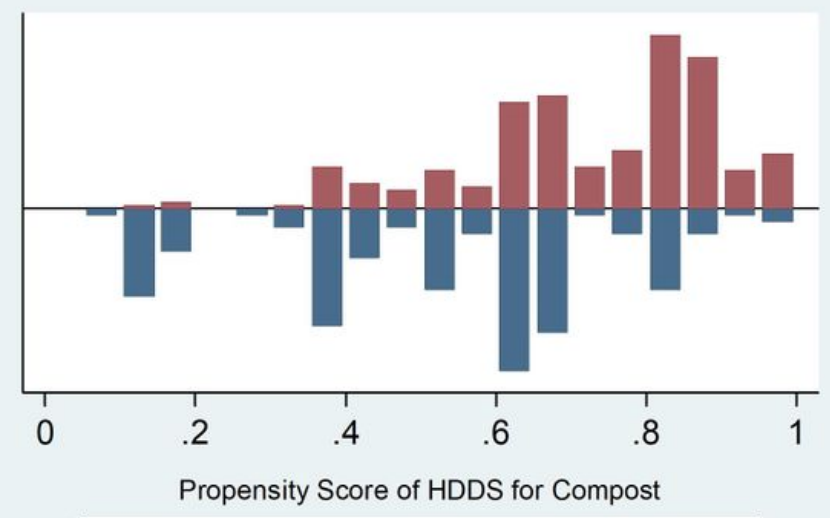

Untreated

Treated

\section{Figure 4}

Common support for propensity score estimation of HDDS for adoption CSA innovations.

\section{Supplementary Files}

This is a list of supplementary files associated with this preprint. Click to download.

- AnnexABC.docx 